\title{
Tensile and Microstructural Behaviors of Austenitic Stainless Steel GTA Welds for Cryogenic Application
}

\author{
극저온용 오스테나이트계 스테인리스강 GTAW 용접부의 \\ 인장 및 미세조직 거동 \\ Woosung Yang*,**, Woong Kil*, Byungrok Moon**, Hyunbin Nam**,†† \\ and Namhyun Kang**, $\dagger$ \\ *Welding Research Institute, ESAB SeAH Corp., Changwon, 51553, Korea \\ **Department of Materials Science \& Engineering, Pusan National University, Busan, 46241, Korea \\ †,†+Corresponding author : †nhkang@pusan.ac.kr, †hbnam12@pusan.ac.kr \\ (Received April 1, 2020 ; Revised April 20, 2020 ; Accepted June 15, 2020)
}

\begin{abstract}
This study investigates the weldability of gas tungsten arc (GTA) on stainless steel (STS) 304 using STS 308L filler and elucidates the cryogenic properties in STS 304 weld. GTA welding were performed with welding current of 90 A, welding velocity of $10.5 \mathrm{~cm} / \mathrm{min}$, Ar shielding gas, and in a single-pass. The GTA welding conditions were configured to ensure a full penetrating weld. For full penetration weld metal (WM), a small amount of $\delta$-ferrite formed. Additionally, the WM of STS 304 exhibited larger dendrite packets compared to the grain size of base metal (BM). Therefore, the drop of hardness in WM was more significant compared to BM. The GTA welds had tensile properties that were inferior to BM at $298 \mathrm{~K}$, and the tensile fracture occurred near the centerline of the transverse welds. The cryogenic tensile strength of GTA welds was superior to the room-temperature property due to the significant phase transformation of martensite at $77 \mathrm{~K}$. However, the elongation decreased.
\end{abstract}

Key Words : Austenitic stainless steel, GTA welding, Microstructure, Mechanical properties, Cryogenic properties

\section{Introduction}

With the recent increase in global LNG usage owing to various environmental regulations, the demand for cryogenic facilities such as LNG ships, pipelines, and LNG storage tanks has been growing ${ }^{1)}$. In particular, the requirement for cryogenic strength and toughness has expanded as the development of natural gas in the deep sea or polar regions has been actively underway $^{2,3)}$. Austenitic stainless steel, which is currently mostly applied to cryogenic equipment, especially such as valves and pipelines, has been known to have excellent cryogenic properties such as strength and toughness even at low temperatures because of its properties of transformation induced plasticity (TRIP) ${ }^{4,5}$. When pipelines of cryogenic structures are welded, gas tung- sten arc welding (GTAW) is mainly applied, which can minimize the deformation of welds with low heat input, does not require re-welding inside pipelines thanks to back bead formation, and has a beautiful weld appearance. The type of welding consumables according to the base metal (BM) has also an influence on weldability.

When austenitic stainless steel is welded, high temperature and solidification cracks may occur because of impure elements $(\mathrm{P}, \mathrm{S})$ in the steel that influence cracking susceptibility, and the integrity of welds are affected by whether or not such cracks occur ${ }^{6,7)}$. It is known that a small amount of $\delta$-ferrite formed during welding of stainless steel has high solubility of $\mathrm{P}$ and $\mathrm{S}$ compared to austenite, thus reducing the sensitivity of solidification cracking ${ }^{8,9)}$, and by applying this effect, it is possible to reduce solidification cracks that may occur during welding. It is also known that stainless steel 
undergoes phase transformation from austenite to martensite in cryogenic regions, thus leading to nonlinear hardening ${ }^{10-12)}$. That is, after the first yield, a phenomenon is seen where strength and elongation significantly increase while going through threshold strain and then additional second hardening ${ }^{11,12}$. Additionally, since austenite stabilizing elements are reduced for stainless steel because of the main Fe component, deformationinduced martensite is formed in the $\gamma$-austenite structure even at room temperature when external stress is exerted. It is known that the increase in deformation induces reduction in the stacking fault energy (SFE), thus the deformation mechanism changes from slip $\rightarrow$ twin $\rightarrow \varepsilon$-martensite transformation behavior ${ }^{13-15)}$. When deformation increases rapidly due to the decrease in test temperature, the fraction of the deformation mechanism is dominantly increased and $\varepsilon$-martensite is transformed into $\alpha$-martensite. Therefore, the variation in the SFE, which is a function of the chemical composition of a material and temperature, plays a crucial role in the cryogenic mechanism of stainless steel. Although studies on the cryogenic strength of this stainless steel have been conducted mainly related to the BM, there has been no research on the mechanism for the cryogenic strength of stainless steel welds in relation to changes in microstructure. Therefore, in this study, we aim to evaluate the weldability of austenitic stainless steel, and identify the mechanism of cryogenic properties by comparing the tensile strength properties at room and cryogenic temperatures.

\section{Experimental method}

For the BM used in this study, among the various types of austenite stainless steel (STS), we performed solution treatment of STS 304 cold-rolled steel sheet at $1040^{\circ} \mathrm{C}$ for 1 hour, and then water-cooled it to prepare the sheet with a thickness of a $1.5 \mathrm{~mm}$. The size of the STS 304 sheet is $55 \mathrm{~mm}(\mathrm{~W}) \times 100 \mathrm{~mm}(\mathrm{~L}) \times 1.5 \mathrm{~mm}$ (T). We also prepared a groove angle of $30^{\circ}$, a root face length of $0.5 \mathrm{~mm}$, and a root gap of $0.5 \mathrm{~mm}$ for feeding filler metal. In addition, in order to fill the space of V-groove, we applied STS 308L filler metal. The chemical composition of the BM and filler metal used in this study is shown in Table 1. In this study, we also

Table 1 Chemical composition of the base metal and filler metal

\begin{tabular}{|c|c|c|c|c|c|c|c|c|c|}
\hline & $\mathrm{C}$ & $\mathrm{Si}$ & $\mathrm{Mn}$ & $\mathrm{Ni}$ & $\mathrm{Cr}$ & $\mathrm{P}$ & $\mathrm{S}$ & $\mathrm{Mo}$ & $\mathrm{Fe}$ \\
\hline $\begin{array}{c}\text { Base } \\
\text { metal }\end{array}$ & 0.06 & 0.44 & 1.04 & 8.03 & 18.1 & 0.03 & 0.01 & - & Bal. \\
\hline $\begin{array}{c}\text { Filler } \\
\text { metal }\end{array}$ & 0.01 & 0.41 & 1.60 & 10.1 & 20.0 & - & - & 0.1 & Bal. \\
\hline
\end{tabular}

performed single-pass GTAW by applying a welding current of $90 \mathrm{~A}$, welding speed of $10.5 \mathrm{~cm} / \mathrm{min}$, and filler metal of $2.0 \Phi$, which were optimal conditions to achieve fully penetrated welds.

We observed the macro and microstructure of the weld through the backscattered electron (BSE) mode of scanning electron microscopy (SEM), and analyzed the crystal structure of the weld using STS 308L filler metal and STS 304 BM through X-ray diffraction (XRD). We observed the microstructural behavior, grain size and phase fraction of the weld through electron backscattered diffraction (EBSD), and performed the quantitative analysis and mapping of electron-probe microanalysis (EPMA) to confirm the component behavior of the weld.

In order to identify the mechanical properties of the $\mathrm{BM}$ and the weld, we observed the hardness of the weld for 10 seconds with a load of 2.942 N (300 gf) using a micro vickers hardness tester, and measured the position $0.5 \mathrm{~mm}$ below the surface of the weld at an interval of $0.5 \mathrm{~mm}$. After fabricating a sub-size specimen of ASTM E8 ${ }^{16)}$ in the vertical direction of the welding line by taking into account the thin sheet BM, we performed the tensile test with the strain rate of $8.3 \times 10^{-4} \mathrm{~s}^{-1}$ at room temperature $(298 \mathrm{~K})$ and cryogenic temperature $(77 \mathrm{~K})$. In addition, by observing the microstructure around the fracture surface after the tensile test, we analyzed the mechanism of cryogenic properties.

\section{Experimental results}

\subsection{Component behavior and microstructure of GTA weld}

Fig. 1a shows the shape of the weld cross-section of the GTA weld using STS 308L filler. No macro-defects such as pores and cracks were observed in the GTA weld. The upper bead was flat, but the lower bead achieved fully penetrated welds with a somewhat convex shape. Fig. 1b shows the components of the GTA weld through the EPMA line analysis. As seen in Fig. 1a, the EPMA line analysis was performed along the area indicated by the red dotted line from the STS 304 BM to the centerline of the weld metal (WM). As clearly seen in Table 1, the chemical composition of the main alloy components (C, Mn, Ni and $\mathrm{Cr}$ ) of the STS 308L filler metal is higher than that of the STS 304 BM. Therefore, it confirmed that the $\mathrm{C}, \mathrm{Mn}, \mathrm{Ni}$, and $\mathrm{Cr}$ component behavior of the WM was slightly higher than that of the BM. This has an influence on the macro and micro component segregation of the weld. In addition, the reason for the irregularity of the main component behavior near the fusion line is considered to be the dilu- 
(a)

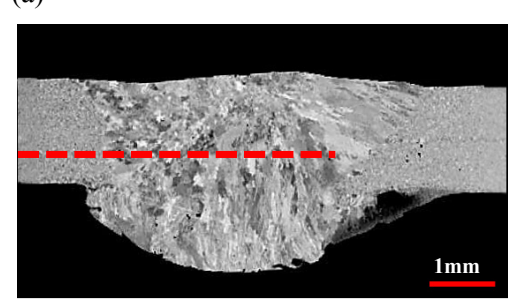

(b)

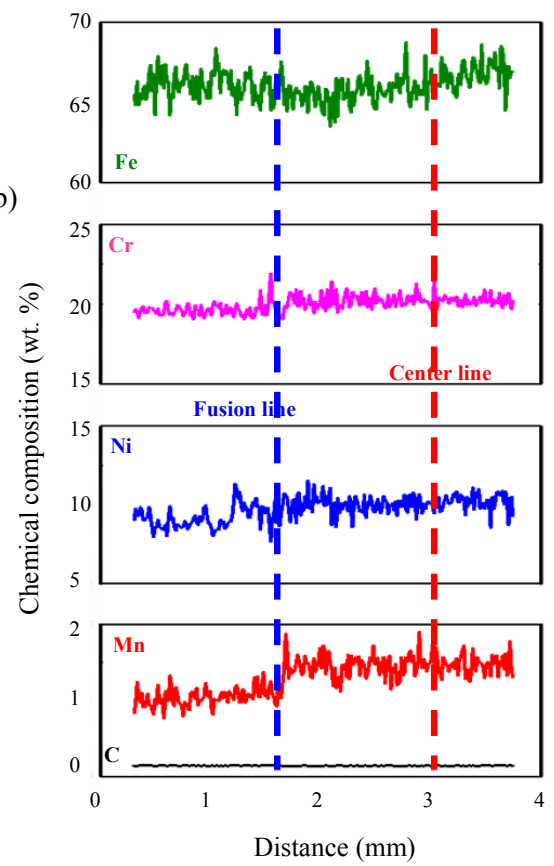

Fig. 1 GTA weld using STS 308L filler: (a) Weld pool shape and (b) Component behavior along the red-dotted line noted in Fig. 1a
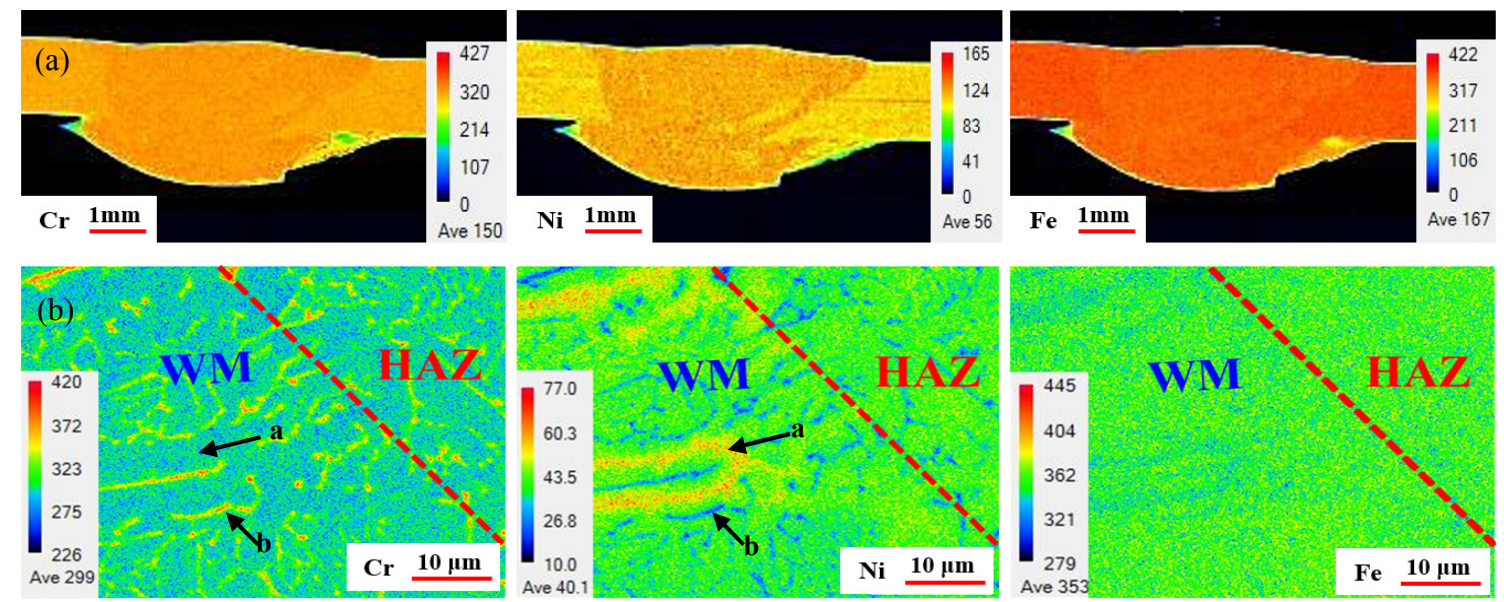

Fig. 2 Component segregation of the GTA weld using STS 308L filler: (a) macro- and (b) micro-segregation behavior

tion of the main components in the heat-affected zone (HAZ) and the WM.

Figs. $2 \mathrm{a}$ and $2 \mathrm{~b}$ show the macro and micro component segregation behavior of the GTA weld using the STS 308L filler, respectively. Through macro and micro mapping of EPMA, we analyzed the segregation behavior of $\mathrm{Ni}, \mathrm{Cr}$, and $\mathrm{Fe}$, which were the main components of the STS 304 BM and WM. Since there was little color difference between the BM and the WM, there was little macro segregation behavior of each component (Fig. 2a). The microstructure of the HAZ and the WM shows equiaxed and columnar shapes, respectively. It confirmed that the $\mathrm{Cr}$ component, which is a ferritestabilizing element, is mainly segregated at the grain boundary and interdendritic region, that the Ni component, which is an austenite-stabilizing element, is mainly segregated at the dendrite core, and that the Fe component is consistently present in all regions. Therefore, it can be predicted that the dendrite core contains austenite while the interdendritic regions and grain boundaries contain $\delta$-ferrites ${ }^{17,18)}$. In addition, in order to confirm the component behavior of each region, the results of the component analysis of the main components of dendrite core and the interdendritic region are shown in Table 2.

For the GTA weld of stainless steel, by applying the quantitative components $\left(\mathrm{Cr}_{\mathrm{eq}}, \mathrm{Ni}_{\mathrm{eq}}\right)$ of the $\mathrm{WM}$ to the Schaeffler diagram, it is possible predict the phase 
Table 2 Chemical composition of elements at the marked area $(a, b)$ in Fig. $2 b$ [wt. \%]

\begin{tabular}{|c|c|c|c|c|c|c|}
\hline & $\mathrm{C}$ & $\mathrm{Mn}$ & $\mathrm{Ni}$ & $\mathrm{Cr}$ & $\mathrm{Si}$ & $\mathrm{Fe}$ \\
\hline a-dendrite core & 0.08 & 2.4 & 9.7 & 18.3 & 0.32 & 69.2 \\
\hline b-interdendritic region & 0.1 & 1.5 & 3.5 & 26.0 & 0.4 & 68.5 \\
\hline
\end{tabular}

formed in the weld. $\mathrm{Cr}_{\mathrm{eq}}$ and $\mathrm{Ni}_{\mathrm{eq}}$ near the centerline of the WM in this study were calculated as follows ${ }^{19,20)}$.

$$
\begin{aligned}
& \mathrm{Cr}_{\mathrm{eq}}=(\mathrm{Cr})+(\mathrm{Mo})+1.5(\mathrm{Si})+0.5(\mathrm{Nb})=12.2 \\
& \mathrm{Ni}_{\mathrm{eq}}=(\mathrm{Ni})+30(\mathrm{C})+0.5(\mathrm{Mn})=20.7
\end{aligned}
$$

Fig. 3 shows the result of the Schaeffler diagram of the STS $304 \mathrm{WM}$ using the STS 308L filler. Austenite and $\delta$-ferrite could be formed in the $\mathrm{WM}^{9)}$, and $\delta$-ferrite was predicted to be $7 \%$.

To prove the predicted results through the Schaeffler diagram, we performed phase analysis through XRD. Fig. 4 shows the XRD patterns of the STS 304 BM and

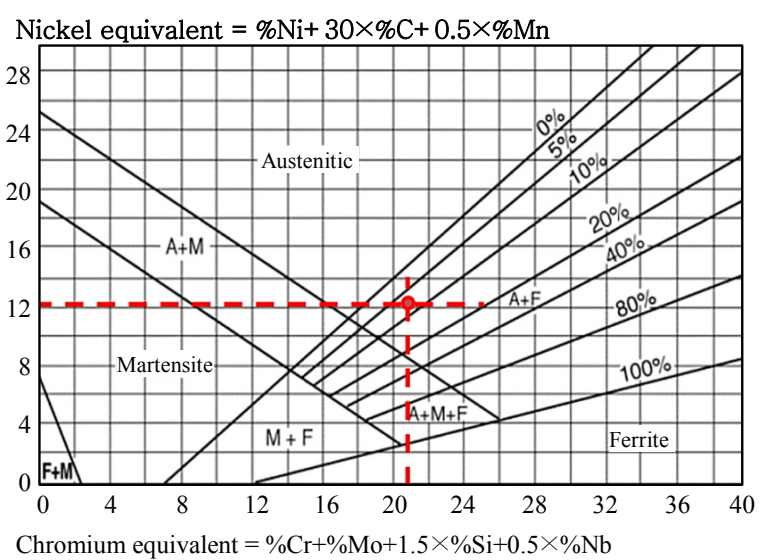

Fig. 3 Formation of $\delta$-ferrite calculated using Schaeffler diagram

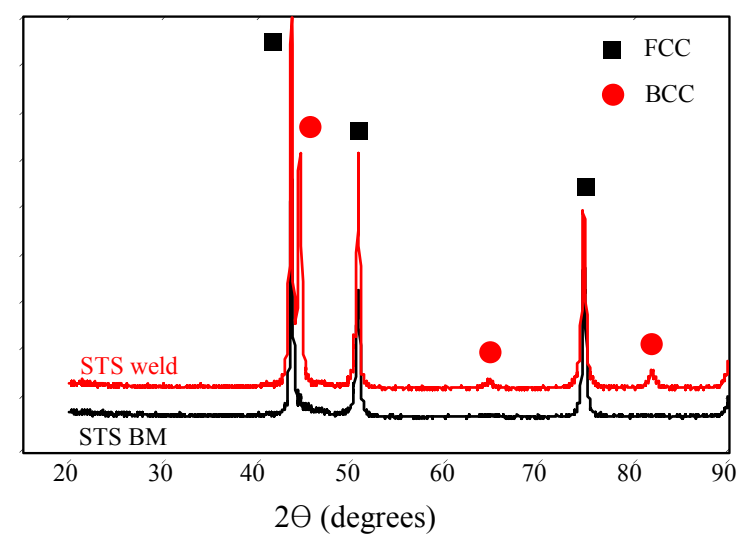

Fig. 4 XRD patterns of STS 304 BM and GTA weld using STS 308L filler weld using the STS 308L filler. The diffraction peaks $\left(2 \theta=43.4^{\circ}, 51.6^{\circ}, 74.7^{\circ}\right)$ of the FCC single phase were observed in the STS $304 \mathrm{BM}$, but the diffraction peak of the FCC and BCC composite phase coexisted in the GTA weld. Normally, when the STS 304 BM is welded using the STS 308L filler, a certain amount of $\delta$ ferrite can be formed in the weld ${ }^{9,10}$. Therefore, as predicted by the Schaeffler diagram, we were able to confirm that austenite and $\delta$-ferrite coexisted in the GTA weld.

Fig. 5 shows the microstructural behavior from the STS 304 BM to the centerline of the weld using the STS 308L filler. The STS 304 BM has a microstructure containing approximately $20 \pm 2 \mu \mathrm{m}$ equiaxed grains and a small amount of twin because of recrystallization and grain growth during solution heat treatment. As seen in Fig.4, we confirmed that it consisted mainly of FCC single phases (Fig. 5a). The microstructure of the $\mathrm{HAZ}$ near the fusion line was similar to that of the BM, but the grain size became slightly coarser than that of the BM (approximately $22 \pm 2 \mu \mathrm{m}$ ). In particular, near the fusion line, it confirmed the formation of $\delta$-ferrite along the grain boundary caused by welding heat. The WM near the fusion line has the same crystal orientation based on the fusion line, and columnar grains grown in one direction are observed. The division between these columnar grains is distinguished by the color difference according to the crystal orientation in the inverse pole figure (IPF) map of Fig. $5 \mathrm{~b}$, and the interface between the grains is represented by the grain boundary. In addition, $\delta$-ferrite was observed along the interdendritic region classified as low-angle grain boundary within the grains. In general, through the austenite single-phase solidification (A-mode), and two-phase solidification of austenite- $\delta$-ferrite (AF- mode) and $\delta$-ferriteaustenite (FA-mode) caused by the welding heat generated during welding of stainless steel, $\delta$-ferrite is crystallized $^{8}$. In addition, $\varepsilon$-martensite was observed locally in the WM and the HAZ near the fusion line, which was caused by the occurrence of tensile/compressive stress due to the fusion and solidification process generated during welding (Fig. 5(b)). The columnar grains were grown in one direction toward the centerline of the weld, and the formation of equiaxed grains was observed at the centerline of the weld. The microstructure at the centerline of the weld had coarse grain size, and consisted of austenite and approximately $6.8 \%$ vermicular $\delta$-ferrite (Fig. 5(c)). This result is almost the same as the ferrite formation level predicted to be $7 \%$ in Fig. 3.

\subsection{Mechanical properties of the GTA weld}

\subsubsection{Hardness properties of the GTA weld}

Figs. $6 \mathrm{a}$ and $6 \mathrm{~b}$ show the hardness distribution and 
(a)

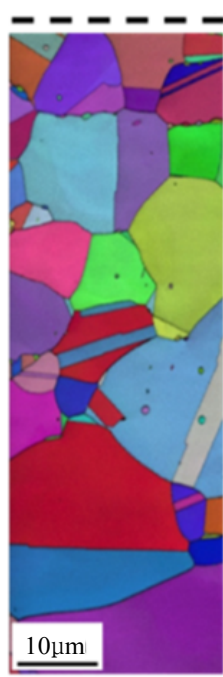

(b)

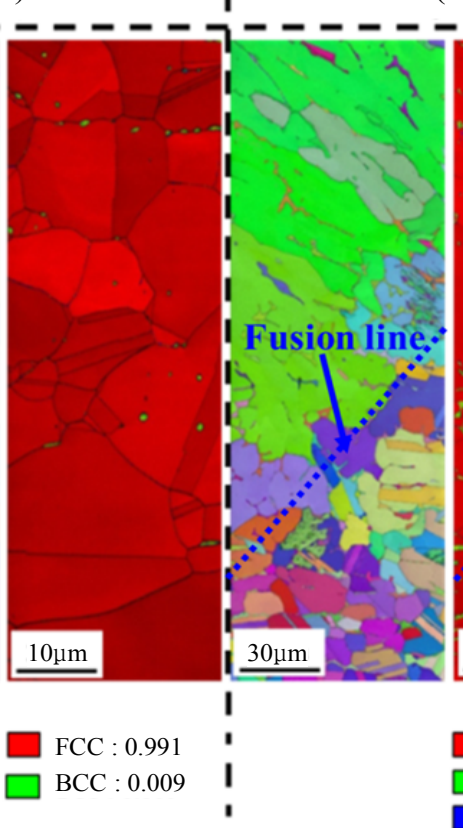

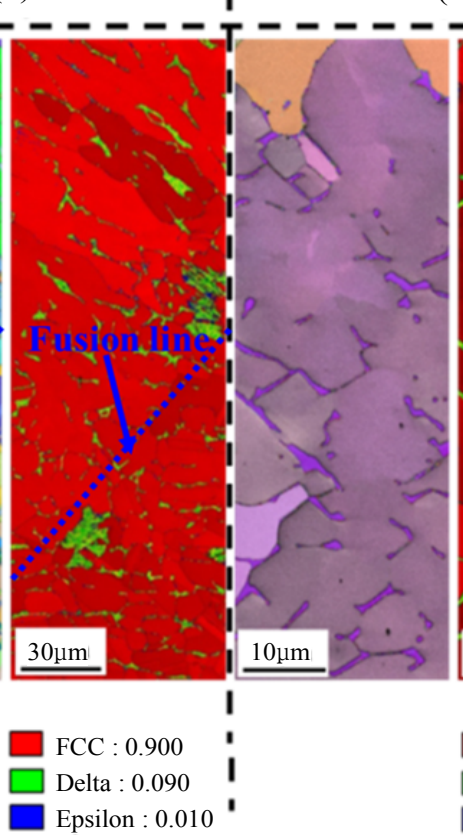

(c)

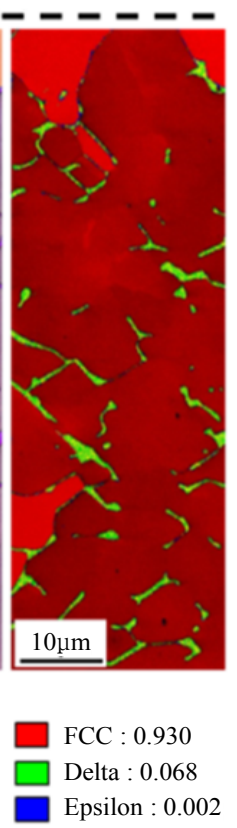

Fig. 5 Microstructural behavior of the GTA weld using STS 308L filler: (a) STS 304 BM, (b) fusion line, (c) STS 308L WM centerline

grain size of each region in the GTA weld using STS 308L filler, respectively. As seen in Fig. 5a, the STS 304 BM was composed of the austenite single-phase, and the average hardness of the BM was measured to be approximately $188 \pm 1 \mathrm{Hv}_{0.3}$ since it has the grain size of approximately $20 \pm 2 \mu \mathrm{m}$. As it gets closer to the fusion line, the grain size of the HAZ becomes slightly coarse, but the hardness distribution tends to increase due to the formation of $\delta$-ferrite by welding heat. In addition, the hardness distribution that tends to increase rapidly in the HAZ near the fusion line is observed, which is considered to be attributed to the presence of Cr-rich carbides ${ }^{21)}$ formed based on the fusion line and $\varepsilon$-martensite formed locally (Fig. 6c). The hardness distribution decreases rapidly from the fusion line toward the centerline of the $\mathrm{WM}$, and the average hardness of the WM is $180 \pm 1 \mathrm{Hv}_{0.3}$, which is approximately $8 \mathrm{Hv}$ lower than the BM. The main reason for this result is considered to be because the grain size of the BM is approximately 6 times finer than the columnar grains (approximately $120 \pm 2 \mu \mathrm{m}$ ) of the WM (Fig. $6 b)$. Since the columnar dendrites grew in one direction from the grains of the HAZ while going through the fusion and quenching steps by the welding heat source, the grain size of the HAZ and the dendrite arm spacing of the WM were almost similar. However, the grain size for the longitudinal direction of the columnar dendrite showed a difference.

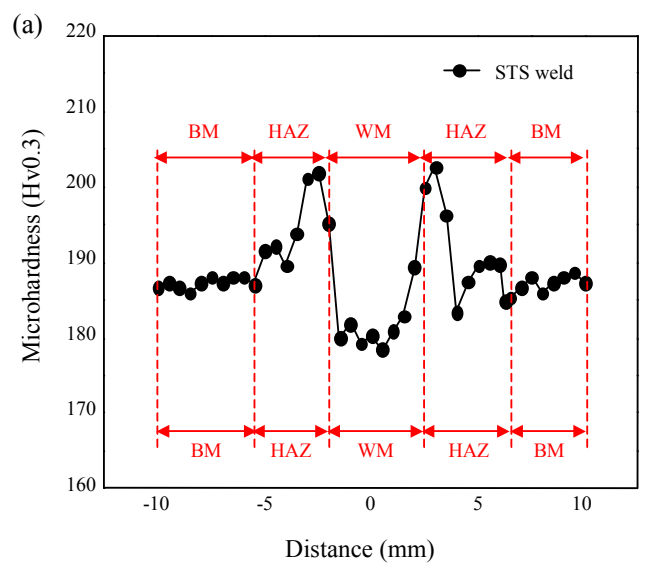

(b)
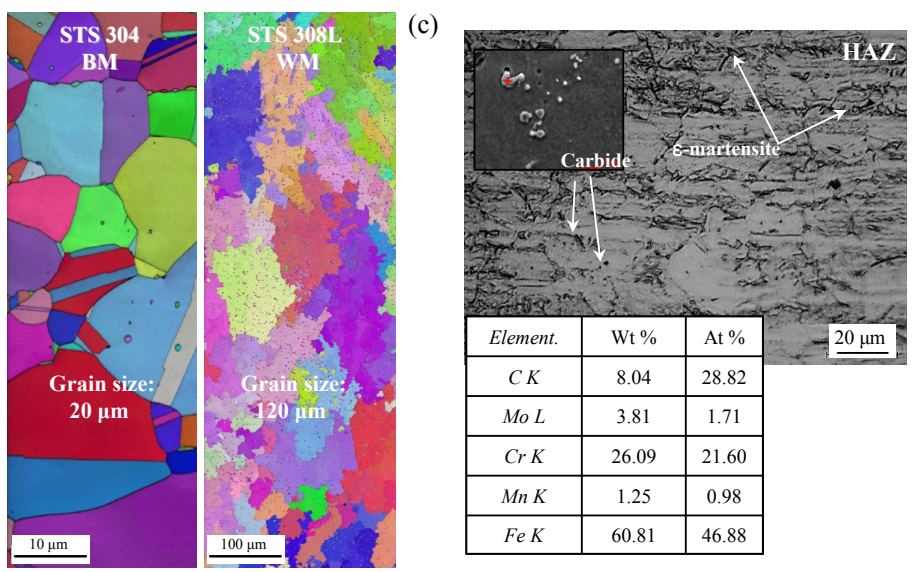

Fig. 6 Characteristics of GTA weld using STS 308L filler: (a) Hardness distribution, (b) grain size in BM/weld centerline, and (c) presence of carbide and $\varepsilon$-martensite in HAZ 
(a)

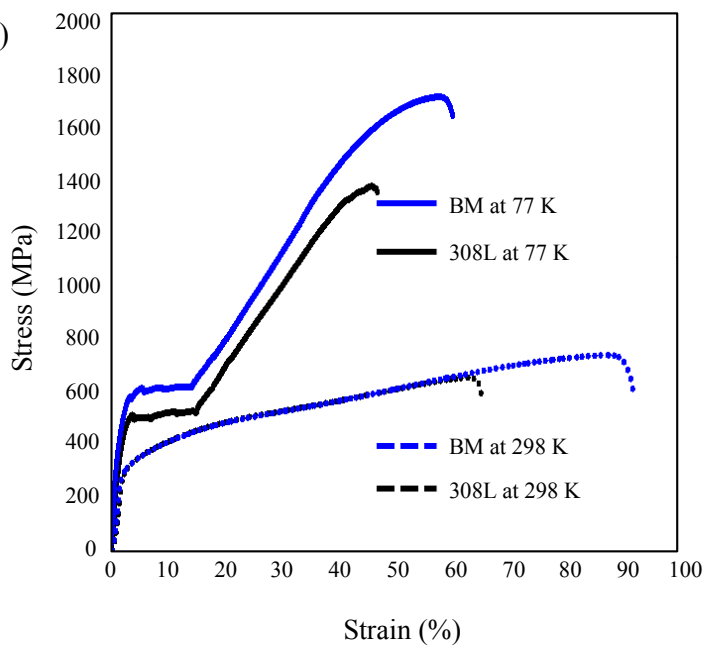

(b)

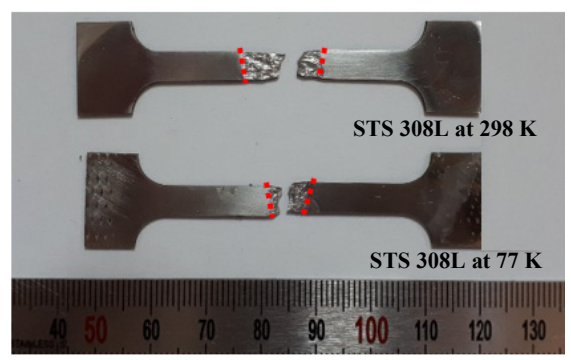

Fig. 7 Tensile properties of STS 304 BM and GTA welds using STS 308L filler tested at 298 and 77 K: (a) tensile stress-strain curves and (b) fracture positions in the welds

\subsubsection{Tensile properties of the GTA weld at room and cryogenic temperature}

Figs. $7 \mathrm{a}$ and $7 \mathrm{~b}$ show the results of stress-strain curves and tensile fracture positions of the STS 304 BM and the GTA weld using the STS 308L filler. We performed tensile tests at room $(298 \mathrm{~K})$ and cryogenic $(77 \mathrm{~K})$ temperatures. With the decrease in test temperature from $298 \mathrm{~K}$ to $77 \mathrm{~K}$, the yield strength (YS) and tensile strength (TS) of the STS 304 BM increased by $43 \%$ and $55 \%$, respectively, but the elongation decreased by approximately $30 \%$. Regardless of tensile test temperature, the tensile properties of the weld showed more degradation than the BM. As described in Fig. 6b, this is because tensile fracture occurred at the centerline of the relatively weak WM by the coarse grain size of the WM compared to the BM. However, the cryogenic tensile properties of the BM and the weld showed better results than the room temperature tensile properties. Specially, the secondary hardening region after the first yield at the cryogenic temperature was clearly seen for both the BM and the weld test specimen, thus the weld was found to show the same cryogenic temperature tensile properties as the $\mathrm{BM}^{11,22)}$.

Figs. $8 \mathrm{a}$ and $8 \mathrm{~b}$ show microstructures in the vicinity of (a)

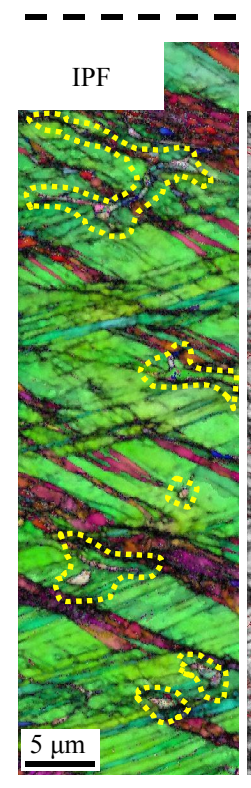

$\Sigma 3$ boundary

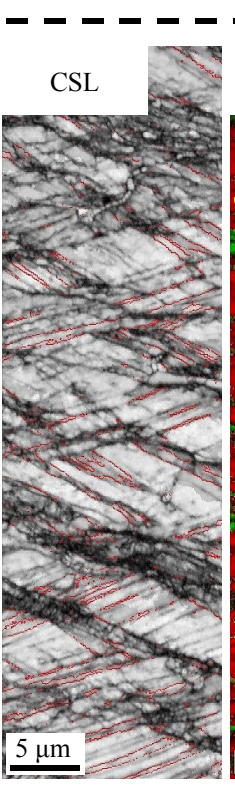

austenite

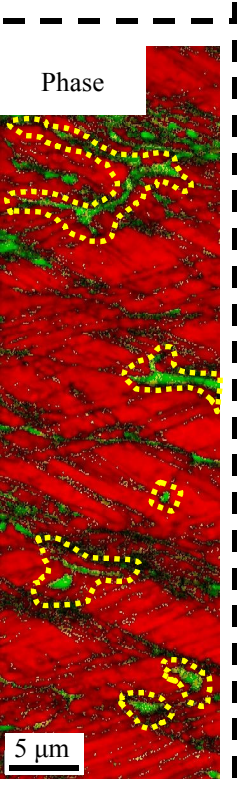

$\alpha^{\prime}$-martensite (b)

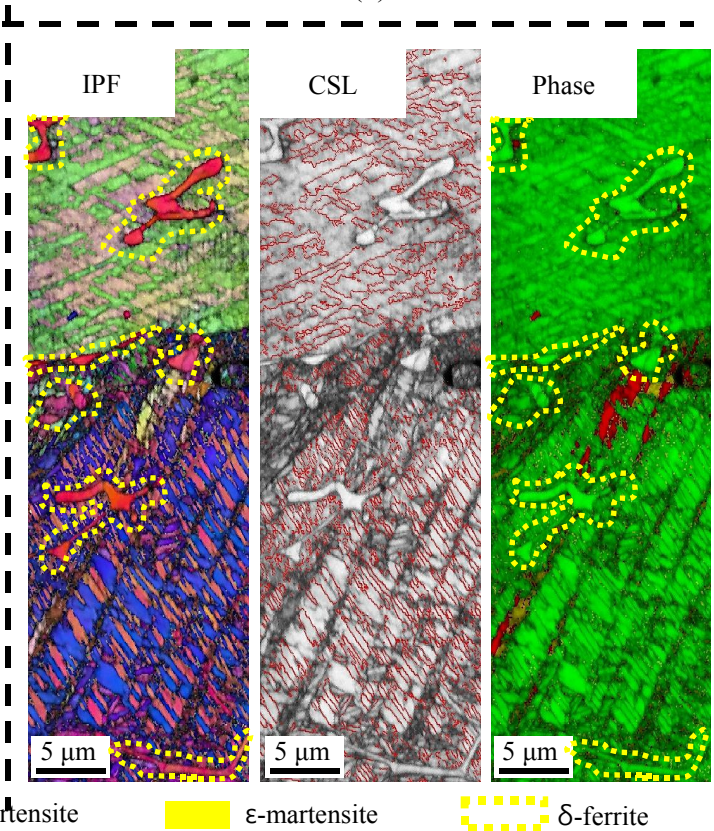

Fig. 8 EBSD microstructures near the tensile fracture position of the weld using STS 308L filler at various temperatures: (a) $298 \mathrm{~K}$ and (b) $77 \mathrm{~K}$ 
the tensile fracture region at room $(298 \mathrm{~K})$ and cryogenic $(77 \mathrm{~K})$ temperatures of the GTA weld using the STS 308L filler. We analyzed the microstructure of each region by applying the inverse pole figure (IPF), coincidence site lattice (CSL) boundary, and phase map of EBSD. Regardless of tensile test temperature, all weld specimens were fractured at the centerline of the WM. In order to investigate the mechanism of excellent cryogenic tensile properties of the weld, it observed whether deformation twin and martensite phase transformation by transformation induced plasticity (TRIP) occurred. Whether deformation twin was formed or not was represented by the CSL boundary of $\Sigma 3$ indicated by a red line in the IQ image. In addition, as for martensite phase transformation, by observing the formation of martensite and the fraction through the phase map, we confirmed main strengthening mechanism. In general, deformation twin and strain-induced martensite transformation occur in austenitic stainless steels when stress is exerted, and these structures depend on the stacking fault energy (SFE). The SFE generated by the destruction of the crystal structure of the atomic arrangement present in the metal varies depending on the alloy element, temperature, grain size, etc. In particular, it is known that the SFE is greatly reduced depending on the change in temperature $(289 \mathrm{~K}-77 \mathrm{~K})$, and the fraction of deformation twin and martensite phase transformation increases sharply at cryogenic temperatures $^{23,24)}$.

A small amount of deformation twin and martensite phase transformation were formed in the microstructure of the weld at room temperature. In the case of the WM using the STS 308L filler, deformation twin and martensite phase transformation may be formed when stress is exerted even at room temperature depending on the alloy component and grain size. On the other hand, we confirmed that the fraction of deformation twin and martensite phase transformation for the microstructure in the weld at cryogenic temperature was higher than for that of the room temperature weld. In the room tem- perature tensile test, with the increase in the strain rate, the deformation mechanism changes from slip $\rightarrow$ twin $\rightarrow \varepsilon$-martensite by inducing the reduction in the SFE. However, the strain rate increases sharply with the decrease in test temperature, thus the fraction of deformation mechanism increases and the $\varepsilon$-martensite transforms into $\alpha$-martensite. Therefore, as shown in $8(\mathrm{~b})$, deformation twin and $\alpha$-martensite phase transformation are dominantly formed at the same time. In addition, $\delta$ ferrite, which was present regardless of the change in temperature, was indicated by a yellow dotted line in the IPF and phase map of each test temperature, and it confirmed that the $\delta$-ferrite of the vermicular shape composed in the weld metal before the tensile test was present in a fragmented form. However, since the elongation is reduced compared to the room temperature test specimen, it is considered that the mechanism of excellent cryogenic tensile properties of the GTA weld using STS 308L filler is mainly a strengthening mechanism by martensite phase transformation.

Figs. 9a and 9b show the fracture surface of the GTA weld that was tensile fractured at room and cryogenic temperature, respectively. Coarse dimples were formed in the weld at room temperature, and the brittle fracture surface was observed locally due to the formation of martensite phase transformation (Fig. 9a). However, the dimple size of the fracture surface of the cryogenic weld was finer than that of the room temperature test specimen, and the fraction of the brittle fracture surface also tended to be higher in the cryogenic weld (Fig. $9 b)$. This is considered to be because the formation of deformation twin and martensite phase transformation predominantly occurred in the cryogenic tensile test. This is also related to the reduction of the SFE due to the decrease in test temperature.

\section{Conclusion}

In this study, we investigated the GTA weldability of STS 304 and its applicability in a cryogenic environ-
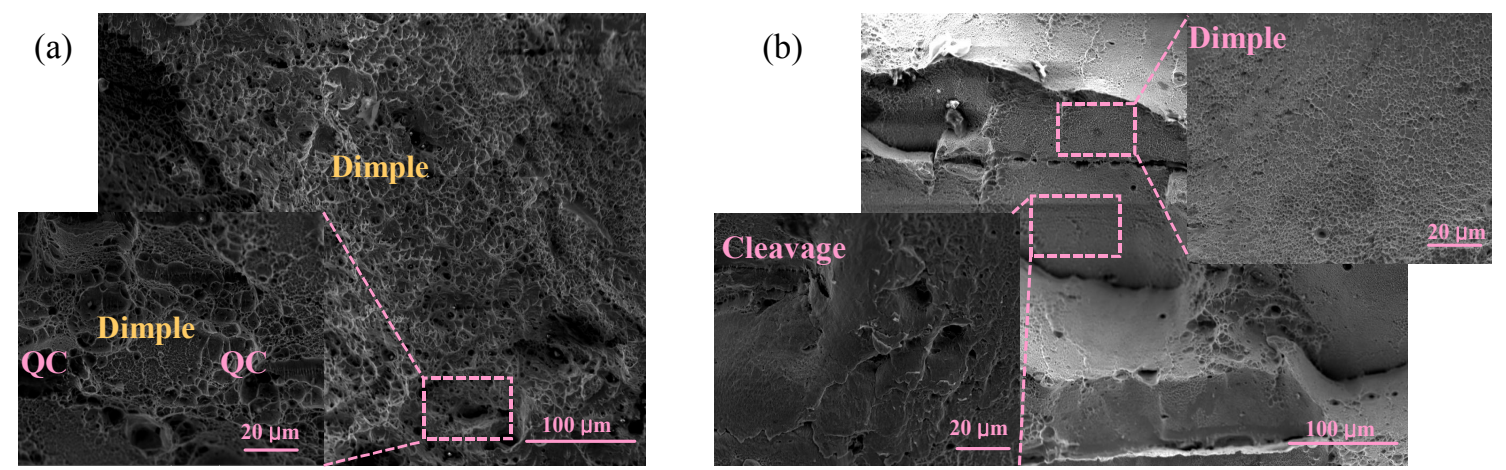

Fig. 9 Fracture surface morphology of the weld using STS 308L filler tested at various temperatures: (a) 298 K and (b) 77 K 
ment of weld using STS 308L filler, and drew the following conclusion.

1) Austenitic and $\delta$-ferrite coexisted in the weld of STS 304 using STS 308L filler. 7\% of $\delta$-ferrite was formed in the interdendritic region of columnar dendrites grown in one direction from the grains of the HAZ near the fusion line by welding heat.

2) The reason that the average hardness of the WM is lower than that of the STS 304 BM is that the grain size of the BM is finer than that of the columnar grain of the WM. The HAZ near the fusion line has higher hardness than the BM because of the presence of local $\varepsilon$-martensite and the formation of carbide.

3) Regardless of the change in tensile test temperature ( $298 \mathrm{~K}-77 \mathrm{~K}$ ), since all the GTA welds showed lower tensile properties than the STS $304 \mathrm{BM}$, tensile fracture of all the welds occurred at the centerline of the WM. However, the STS 304 weld using STS 308L filler showed excellent cryogenic tensile properties compared to those at room temperature as with the STS 304 BM.

4) The improvement of cryogenic tensile properties was attributed to the fact that deformation twin and martensite phase transformation dominantly occurred. However, since the elongation is reduced in the cryogenic GTA weld, the main strengthening mechanism is considered to be the phase transformation of deformation-induced martensite.

\section{Acknowledgment}

This work was supported by the Ministry of Trade, Industry and Energy (MOTIE, Korea) under the Industrial Technology Innovation Program Grant No. 10080728, and the World Class 300 Project R\&D (S2482209) of the MOTIE and MSS (Korea).

ORCID: Woosung Yang: https://orcid.org/0000-0001-6250-2258 ORCID: Byungrok Moon: https://orcid.org/0000-0002-4604-0898 ORCID: Hyunbin Nam: https://orcid.org/0000-0003-3152-9567 ORCID: Namhyun Kang: https://orcid.org/0000-0002-9460-5128

\section{References}

1. S. Kumar, H. T. Kwon, K. H. Choi, J. H. Cho, W. Lim and I. Moon, Current status and future projections of LNG demand and supplies: A global prospective, Energy Policy. 39(7) (2011) 4097-4104. https://doi.org/10.1016/j.enpol.2011.03.067

2. J. H. Kim, S. W. Choi, D. H. Park and J. M. Lee, Charpy impact properties of stainless steel weldment in liquefied natural gas pipelines: Effect of low temperatures, Mater. Design. 65 (2015) 914-922.

https://doi.org/10.1016/j.matdes.2014.09.085
3. W. S. Park, M. S. Chun, M. S. Han, M. H. Kim and J. M. Lee, Comparative study on mechanical behavior of low temperature application materials for ships and offshore structures: Part I-Experimental investigations, Mater. Sci. Eng. A. 528:18 (2011) 5790-5803. https://doi.org/10.1016/J.MSEA.2011.04.032

4. Y. Xu, S. Zhang, H. Song, M. Cheng and H. Zhang, The enhancement of transformation induced plasticity effect on austenitic stainless steels by cyclic tensile loading and unloading, Mater Lett. 65:11 (2011) 1545-1547. https://doi.org/10.1016/j.matlet.2011.02.066

5. W. S. Park, S. W. Yoo, M. H. Kim and J. M. Lee, Strainrate effects on the mechanical behavior of the AISI 300 series of austenitic stainless steel under cryogenic environments, Mater Des. 31:8 (2010) 3630-3640. https://doi.org/10.1016/j.matdes.2010.02.041

6. Shankar V, Gill TPS, Mannan S.L, Sundaresan S. Solidification cracking in austenitic stainless steel welds, Sadhana. 28 (2003) 359-382.

7. J. Yu, M. Rombouts and G. Maes, Cracking behavior and mechanical properties of austenitic stainless steel parts produced by laser metal deposition, Mater. Design. 45 (2013) 228-235.

https://doi.org/10.1016/j.matdes.2012.08.078

8. E. J. Chun, H. Baba, K. Nishimoto and K. Saida, Precipitation of sigma and chi phases in $\delta$-ferrite of Type 316FR weld metals, Mater. Charact. 86 (2013)152-166. https://doi.org/10.1016/j.matchar.2013.10.003

9. F. Mas, C. Tassin, F. Roch, M. Yescas, P. Todeschini and Y. Brechet, Growth Morphologies and Primary Solidification Modes in a Dissimilar Weld between a LowAlloy Steel and an Austenitic Stainless Steel, Metals. 8:284 (2018) 1-21.

https://doi.org/10.3390.met8040284

10. C. Garion, B. Skoczen and S. Sgobba, Constitutive modelling and identification of parameters of the plastic strain-induced martensitic transformation in $316 \mathrm{~L}$ stainless steel at cryogenic temperatures, Int. J. Plast. 22 (2006) 1234-1264.

https://doi.org/10.1016/j.ijplas.2005.08.002

11. J. H. Hong, D. M. Keum, D. S. Han, I. B. Park, M. S. Chun, K. W. Ko and J. M. Lee, Mechanical Characteristics of Stainless Steel under Low Temperature Environment, JSNAK. 45:5 (2008) 530-537. https://doi.org/10.3744/SNAK.2008.45.5.530

12. T. Yuri, T. Ogata, M. Saito and Y. Hirayama, Effect of welding structure and $\delta$-ferrite on fatigue properties for TIG welded austenitic stainless steels at cryogenic temperatures, Cryogenics. 40 (2000) 251-259. https://doi.org/10.1016/S0011-2275(00)00033-3

13. J. H. Noh, S. G. Lee, H. J. Park and N. H. Kang, Effect of Composition on Strain-Induced Martensite Transformation and Tensile Stress-Strain Curve for Austenitic Stainless Steel, J. Weld. Join. 36(2) (2018) 28-33. https://doi.org/10.5781/JWJ.2018.36.2.5

14. A. Das and S. Tarafder, Experimental investigation on 
martensitic transformation and fracture morphologies of austenitic stainless steel, Int. J. Plast. 25(11) (2009) 2222-2247.

https://doi.org/10.1016/j.ijplas.2009.03.003

15. S. Curtze, V. T. Kuokkala, A. Oikari, J. Talonen and H. Hanninen, Thermodynamic modeling of the stacking fault energy of austenitic steels, Acta. Mater. 59(3) (2011) 1068-1076.

https://doi.org/10.1016/j.actamat.2010.10.037

16. ASTM E8/E8M-08, Standard Test Methods for Tension Testing of Metallic Materials, ASTM international.

17. S. K. Park, H. J. Lee and J. H. Lee, Effect of Thermal Aging Induced Microstructure Evolution on Mechanical and Corrosion Properties of Delta-Ferrite in Austenitic Stainless Steel Weld, Korean J. Met. Mater. 56(4) (2018) 296-303.

https://doi.org/10.3365/KJMM.2018.56.4.296

18. H. B. Nam, S. W. Park, N. K. Park, Y. S. Na, H. S. Kim, S. J. Yoo, Y. H. Moon and N. H. Kang, Weldability of cast $\mathrm{CoCrFeMnNi}$ high-entropy alloys using various filler metals for cryogenic applications, J. Alloy. Comp. 819 (2020) 153278.

https://doi.org/10.1016/j.jallcom.2019.153278

19. J. Y. Jung, The Effects of Nitrogen Content and Cold Rolling Reduction on the Mechanical Properties of New 420-series Stainless Steel Strip having a Mesh As-Welded Structure by the Electroslag Cladding, $J$.
Weld. Join. 35(6) (2017) 582-590.

https://doi.org/10.5781/JWJ.2017.35.6.7

20. G. R. Mohammed, M. Iahak, S. N. Aqida and H. Abdulhadi, Effects of Heat Input on Microstructure, Corrosion and Mechanical Characteristics of Welded Austenitic and Duplex Stainless Steels: A Review, Metals. 7(39) (2017) 1-18.

https://doi.org/10.3390/met7020039

21. S. Kumar and A. S. Shahi, Effects of heat input on the microstructure and mechanical properties of gas tungsten arc welded AISI 304 stainless steel joints, Mater. Des. 32 (2011) 3617-3623.

https://doi.org/10.1016/j.matdes.2011.02.017

22. K. L. Ye, H. Y. Luo and J. L. Lv, Producing Nanostructured 304 Stainless steel by Rolling at Cryogenic Temperature, Mater. Manuf. Process. 29 (2014) 754758.

https://doi.org/10.1080/10426914.2014.901534

23. M. H. Choi, J. H. Lee, H. B. Nam, N. H. Kang, M. H. Kim and D. W. Cho, Tensile and Microstructural Characteristics of Fe-24Mn Steel Welds for Crygenic Applications, Met. Mater. Int. 36(2) (2020) 240-247. https://doi.org/10.1007/s12540-019-00320-4

24. A. Das, Revisiting Stacking Fault Energy of Steels, Metall. Mater. Trans. A. 47A (2016) 748-768. https://doi.org/10.1007/s11661-015-3266-9 


\title{
극저온용 오스테나이트계 스테인리스강 GTAW 용접부의 인장 및 미세조직 거동
}

\section{Tensile and Microstructural Behaviors of Austenitic Stainless Steel GTA Welds for Cryogenic Application}

\author{
양우성**** 길 웅** 문병록** 남현빈** · 강남현** \\ *세아에삽 기술연구소 \\ **부산대학교 재료공학과
}

\section{1. 서 론}

최근 다양한 환경규제로 인한 세계적인 $\mathrm{LNG}$ 사용량 증가 추세에 따라 $\mathrm{LNG}$ 선박, 파이프 라인 및 $\mathrm{LNG}$ 저장탱크 등의 극저온용 설비 수요가 증가되고 있다 ${ }^{11}$. 특히, 심해나 극지의 천연가스 개발이 활발하게 이루어 짐에 따라 극저온 강도 및 인성에 대한 요구가 확대되 었다 ${ }^{2,3)}$. 현재 극저온용 장비, 특히 밸브 및 배관 등에 대부분 적용되고 있는 오스테나이트계 스테인레스강은 변형유기소성 (Transformation induced plasticity, TRIP)의 특성으로 인하여 저온에서도 강도 및 인성 등 의 극저온 물성이 우수하다고 알려져 있다 ${ }^{4,5)}$. 극저온 용 구조물의 배관(Pipe line) 용접 시, 낮은 입열량으 로 용접부 변형을 최소화 할 수 있고 이면 비드 형성으 로 인하여 배관 내부 재용접이 불필요하며 미려한 용접 부 외관을 가질 수 있는 GTAW(Gas tungsten arc welding)이 주로 적용되며, 모재에 따른 용접재료의 종류도 용접성에 영향을 미친다.

오스테나이트계 스테인리스강(이하 스테인리스강)의 용접 시, 강 중에서 균열 감수성에 영향을 미치는 불순 물 원소 $(\mathrm{P}, \mathrm{S})$ 에 의하여 고온 및 응고균열이 발생되는 경우가 있으며, 이러한 균열의 발생 여부에 따라 용접 부의 건전성에 영향을 받는다 ${ }^{6,7)}$. 스테인리스강의 용접 중에 형성되는 소량의 $\delta$-페라이트는 오스테나이트에 비 하여 $\mathrm{P}, \mathrm{S}$ 의 고용도가 높아, 응고 균열 민감성을 감소 하는 효과가 있음이 알려져 있으며 ${ }^{8,9)}$, 이러한 효과를 적용하여 용접 시 발생할 수 있는 응고균열의 저감이 가능하다. 또한, 스테인리스강은 극저온 영역에서 오스 테나이트로 부터 마르텐사이트로 상변태가 되면서 비선 형적 경화가 발생된다고 알려져 있다 ${ }^{10-12)}$. 즉, 1 차 항 복이 발생된 이후, 임계 변형율 (Threshold strain)을
거치고 추가적으로 2 차 경화를 거치면서 강도와 연신율 이 현저하게 증가되는 현상을 보여준다 ${ }^{11,12)}$. 추가적으 로, 스테인리스강은 주된 $\mathrm{Fe}$ 성분의 구성으로 인하여 오스테나이트 안정화원소가 감소되므로, 외부 응력(충 격)이 가해지면 상온에서도 $\mathrm{\gamma}$-오스테나이트 구조에서 가공 유기마르텐사이트가 발생된다. 변형이 증가될수록 적층 결함에너지(stacking fault energy: SFE)의 감소를 유발하여 변형기구가 슬립(slip) $\rightarrow$ 쌍정 (twin) $\rightarrow \varepsilon^{-}$ 마르텐사이트로 변태 거동이 변화된다고 알려져 있다 13-15). 시험온도 감소에 의하여 변형이 급속하게 증가되 면 변형기구의 분율이 지배적으로 증가되고, $\varepsilon^{-}$마르텐 사이트가 $a-$ 마르텐사이트로 변태된다. 그러므로 소재의 화학성분 및 온도의 함수인 적층결함에너지의 변화가 스테인리스강의 극저온 메커니즘에 중요한 역할을 한 다. 이러한 스테인리스강의 극저온 강도에 대한 연구가 주로 모재와 관련되어 수행되고 있으나, 스테인리스강 용접부의 극저온 강도에 대한 메커니즘을 미세조직의 변 화와 연계하여 연구한 사례는 전무하다. 따라서 본 연구 에서는 오스테나이트계 스테인리스강의 용접성을 평가 하고, 상온 및 극저온 인장 강도 특성을 비교하여 극저 온 특성의 메커니즘을 규명하고자 한다.

\section{2. 실험방법}

본 연구에 사용된 모재는 오스테나이트계 스테인리스 강 (STS) 중, STS 304의 냉간 압연된 판재를 1040 ${ }^{\circ} \mathrm{C}$ 에서 1 시간 동안 용체화 처리를 한 이후, 수냉을 거 쳐 $1.5 \mathrm{~mm}$ 두께의 판재로 준비하였다. STS 304 판재 의 치수는 $55 \mathrm{~mm}(\mathrm{~W}) \times 100 \mathrm{~mm}(\mathrm{~L}) \times 1.5 \mathrm{~mm}$ (T) 이며, 용가재의 피딩 (feeding)을 위하여 $30^{\circ}$ 의 groove angle와 $0.5 \mathrm{~mm}$ 의 root face length 그리고 $0.5 \mathrm{~mm}$ 의 root gap을 제작하였다. 또한 V-groove의 
Table 1 Chemical composition of the base metal and filler metal

\begin{tabular}{|c|c|c|c|c|c|c|c|c|c|}
\hline & $\mathrm{C}$ & $\mathrm{Si}$ & $\mathrm{Mn}$ & $\mathrm{Ni}$ & $\mathrm{Cr}$ & $\mathrm{P}$ & $\mathrm{S}$ & $\mathrm{Mo}$ & $\mathrm{Fe}$ \\
\hline $\begin{array}{c}\text { Base } \\
\text { metal }\end{array}$ & 0.06 & 0.44 & 1.04 & 8.03 & 18.1 & 0.03 & 0.01 & - & Bal. \\
\hline $\begin{array}{c}\text { Filler } \\
\text { metal }\end{array}$ & 0.01 & 0.41 & 1.60 & 10.1 & 20.0 & - & - & 0.1 & Bal. \\
\hline
\end{tabular}

공간을 채우기 위하여 STS 308L 용접재료를 적용하 였으며, 본 연구에서 사용된 모재와 용접재료의 화학성 분은 Table 1 에 나타내었다. 또한 본 연구에서 용접전 류 $90 \mathrm{~A}$, 용접속도 $10.5 \mathrm{~cm} / \mathrm{min}, 2.0$ Ф의 용접재료 를 적용하여 single-pass의 GTAW를 수행하였으며, 상기 조건은 완전용입된 용접부를 획득할 수 있는 최적 의 조건이었다.

용접부의 매크로 및 미세조직은 주사전자현미경 (scanning electron microscopy, SEM)의 backscattered electron (BSE) 모드를 통하여 관찰되었으며, STS 304 모재 및 STS 308L 용접재료를 적용한 용접부의 결정 구조는 X-ray diffraction (XRD)를 통해 분석하였다. 그리고 용접부의 미세조직 거동, 결정립도 및 상분율은 electron backscattered diffraction(EBSD)를 통하 여 관찰하였으며, 용접부의 성분 거동을 확인하기 위하 여 electron-probe microanalysis (EPMA) 정량분 석 및 맵핑(mapping)을 수행하였다.

모재 및 용접부의 기계적 특성을 파악하기 위하여, 용접부의 경도는 마이크로 비커스 경도기를 사용하여
$2.942 \mathrm{~N}(300 \mathrm{~g})$ 의 하중으로 10 초 동안 유지하였으며, 용접부의 표면에서 아래로 $0.5 \mathrm{~mm}$ 떨어진 위치를 $0.5 \mathrm{~mm}$ 간격으로 측정하였다. 인장시험은 박판재의 모재 크기 를 고려하여 용접선의 수직인 방향으로 $\mathrm{ASTM} \mathrm{E} 8^{16)}$ 의 Sub size 시편을 가공하여, 상온 $(298 \mathrm{~K})$ 및 극저 온 $(77 \mathrm{~K})$ 에서 $8.4 \times 10^{-4} \mathrm{~s}^{-1}$ 의 변형율로 인장시험을 수행하였다. 또한, 인장시험 후 파단부 주위의 미세조 직을 관찰하여 극저온 특성 메커니즘을 분석 하였다.

\section{3. 실험결과}

\subsection{GTA 용접부의 성분거동 및 미세 조직}

Fig. 1a는 STS 308L 용접재료를 적용한 GTA 용 접부의 용접 단면 형상이다. GTA 용접부에서 기공 및 크랙 등과 같은 macro-defects는 관찰되지 않았으며, 상부 비드는 평탄하지만 하부 비드는 다소 볼록한 형상 을 가진 완전 용입된 용접부를 획득하였다. Fig. $1 \mathrm{~b}$ 는 EPMA 선 분석을 통한 GTA 용접부의 성분을 나타낸 다. EPMA 선 분석은 Fig. $1 \mathrm{a}$ 에 나타낸 바와 같이 STS 304 모재로부터 용접금속의 중심선 까지 빨간색 점선으로 표시된 영역을 따라 수행되었다. Table 1에 서 알 수 있듯이, STS 308L 용접재료의 주요 합금성 분 $(\mathrm{C}, \mathrm{Mn}, \mathrm{Ni}$ 및 $\mathrm{Cr})$ 의 화학조성이 $\mathrm{STS} 304$ 모재 보다 높다. 그러므로 용접금속의 $\mathrm{C}, \mathrm{Mn}, \mathrm{Ni}$ 및 $\mathrm{Cr}$ 성 분의 거동이 모재보다 소폭 높은 것을 확인 하였다. 이 러한 경향은 용접부의 매크로 및 미세성분 편석에 영향 (a)

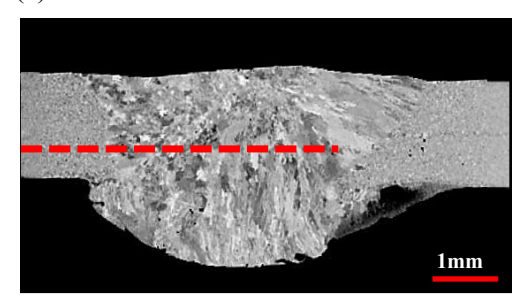

(b)

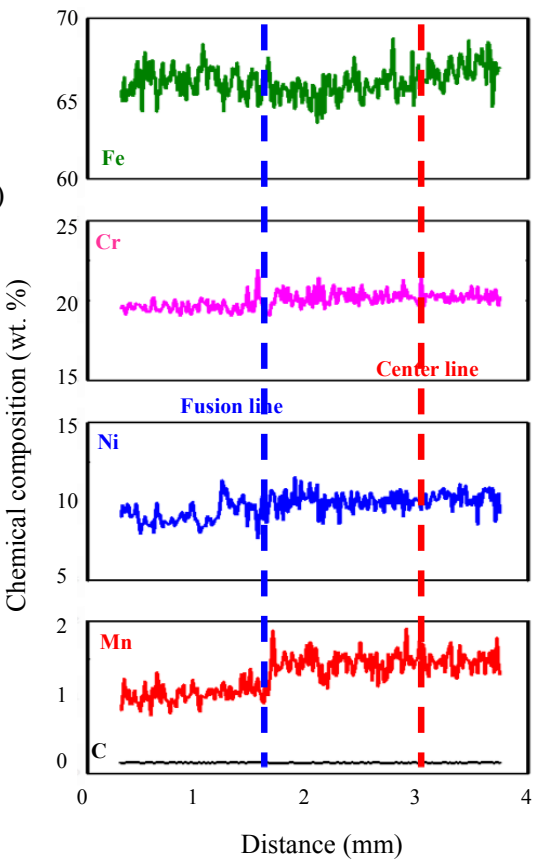

Fig. 1 GTA weld using STS 308L filler: (a) Weld pool shape and (b) Component behavior along the red-dotted line noted in Fig. 1a 

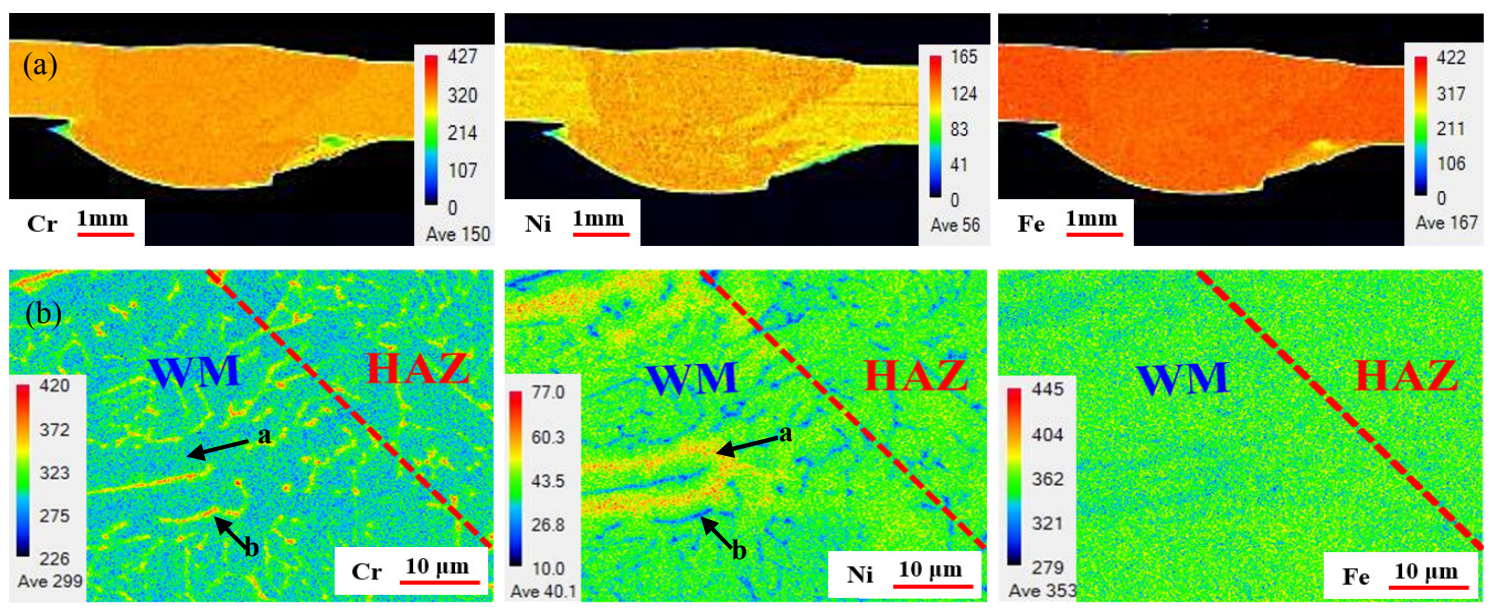

Fig. 2 Component segregation of the GTA weld using STS 308L filler: (a) macro- and (b) micro-segregation behavior

을 미친다. 또한 용융선 부근에서 주요 성분의 거동이 불규칙한 원인은 열영향부와 용접금속에서 주요 성분의 희석이 발생되기 때문으로 판단된다.

Figs. 2a와 2b는 STS 308L 용접재료를 적용한 GTA 용접부의 매크로 및 미세성분 편석 거동을 각각 보여준 다. EPMA의 매크로 및 미세 맵핑을 통하여 STS 304 모재와 $308 \mathrm{~L}$ 용접재료의 주요 성분인 $\mathrm{Ni}, \mathrm{Cr}, \mathrm{Fe}$ 의 편석거동을 분석하였다. 모재와 용접금속 간 색상 차이 는 거의 없으므로 각 성분의 매크로 편석 거동은 거의 없음을 알았다. (Fig. 2a). 열영향부와 용접부의 미세조 직은 각각 등축정 및 주상정 형태를 보인다. 결정립계 에는 페라이트 안정화 원소인 $\mathrm{Cr}$ 성분이 주로 편석되 어 있고, 덴드라이트 중심에서는 오스테나이트 안정화 원소인 $\mathrm{Ni}$ 성분이 주로 편석되어 있음을 확인하였으며, $\mathrm{Fe}$ 는 모든 영역에서 성분이 일정 하였다. 그러므로 덴 드라이트 중심부는 오스테나이트, 아결정립계 및 결정립 계는 $\delta$-페라이트가 포함되어 있음을 예측할 수 있다 ${ }^{17,18)}$. 또한 각 영역의 성분거동을 확인하기 위하여, 덴 드라이트 중심 및 아결정립계의 주요합금 성분에 대한 성분분석 결과를 Table. 2에 나타내었다.

스테인리스강의 GTA 용접부는 용접금속의 정량적 성 분 $\left(\mathrm{Cr}_{\mathrm{eq}}, \mathrm{Ni}_{\mathrm{eq}}\right)$ 을 Schaeffler diagram에 적용하여 용 접부에서 생성되는 상이 예측 가능하다. 본 연구에서 수행된 용접금속 중심선 부근의 $\mathrm{Cr}_{\mathrm{eq}}$ 및 $\mathrm{Ni}_{\mathrm{eq}}$ 를 다음과 같은 식으로 계산하였다 ${ }^{19,20)}$.

Table 2 Chemical composition of elements at the marked area $(\mathrm{a}, \mathrm{b})$ in Fig. $2 \mathrm{~b}$ [wt. \%]

\begin{tabular}{|c|c|c|c|c|c|c|}
\hline & $\mathrm{C}$ & $\mathrm{Mn}$ & $\mathrm{Ni}$ & $\mathrm{Cr}$ & $\mathrm{Si}$ & $\mathrm{Fe}$ \\
\hline a-dendrite core & 0.08 & 2.4 & 9.7 & 18.3 & 0.32 & 69.2 \\
\hline b-interdendritic region & 0.1 & 1.5 & 3.5 & 26.0 & 0.4 & 68.5 \\
\hline
\end{tabular}

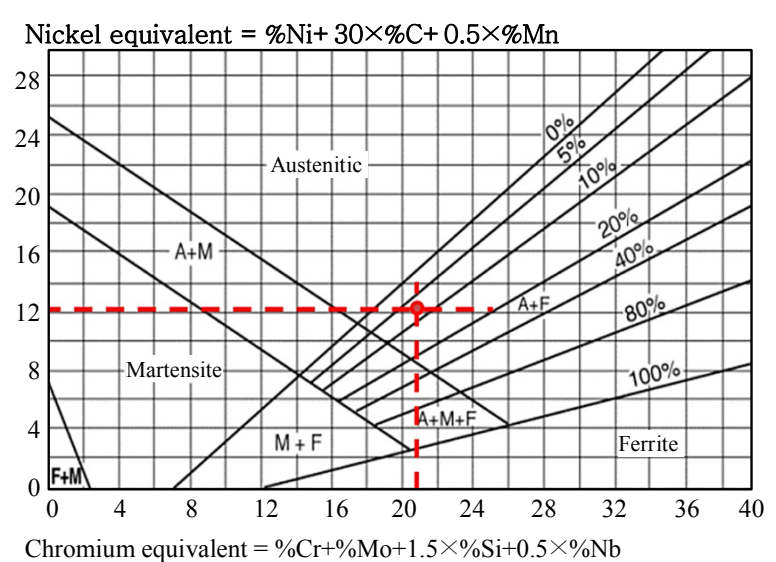

Fig. 3 Formation of $\delta$-ferrite calculated using Schaeffler diagram

$$
\begin{aligned}
& \mathrm{Cr}_{\mathrm{eq}}=(\mathrm{Cr})+(\mathrm{Mo})+1.5(\mathrm{Si})+0.5(\mathrm{Nb})=12.2 \\
& \mathrm{Ni}_{\mathrm{eq}}=(\mathrm{Ni})+30(\mathrm{C})+0.5(\mathrm{Mn})=20.7
\end{aligned}
$$

Fig. 3은 STS 308L 용접재료를 적용한 STS 304 용접금속의 Schaeffler diagram 적용 결과를 나타낸 다. 용접금속에서는 오스테나이트와 $\delta$-페라이트가 생성 가능하였으며 ${ }^{9)}, \delta$-페라이트는 $7 \%$ 수준으로 예측되었다.

Schaeffler diagram을 통해 예측된 결과를 증명하 기 위하여, XRD를 통한 상분석을 수행하였다. Fig. 4 는 STS 308L 용접재료를 적용한 GTA 용접부와 STS 304 모재의 XRD 패턴을 보여준다. STS 304 모재는 $\mathrm{FCC}$ 단상의 회절 피크 $\left(2 \theta=43.4^{\circ}, 51.6^{\circ}, 74.7^{\circ}\right)$ 가 관찰되었으나, $\mathrm{GTA}$ 용접부에서는 $\mathrm{FCC}$ 와 $\mathrm{BCC}$ 복합 상의 회절 피크가 공존하였다. 일반적으로 STS 308L 용접재료를 적용하여 STS 304 모재를 용접하는 경우, 용접부에 일정량의 $\delta$-페라이트가 생성될 수 있다 ${ }^{9,10)}$. 그러므로 Schaeffler diagram을 통해 예측된 결과와 같이, GTA 용접부는 오스테나이트 및 $\delta$-페라이트가

본 논문은 독자의 이해를 돕기위하여 영문논문을 국문으로 번역하여 게재한 논문입니다. 저자는 본 논문으로 연구업적과 같은 실적에 중복으로 지원받거나 인정받을 수 없음을 알려드립니다. 


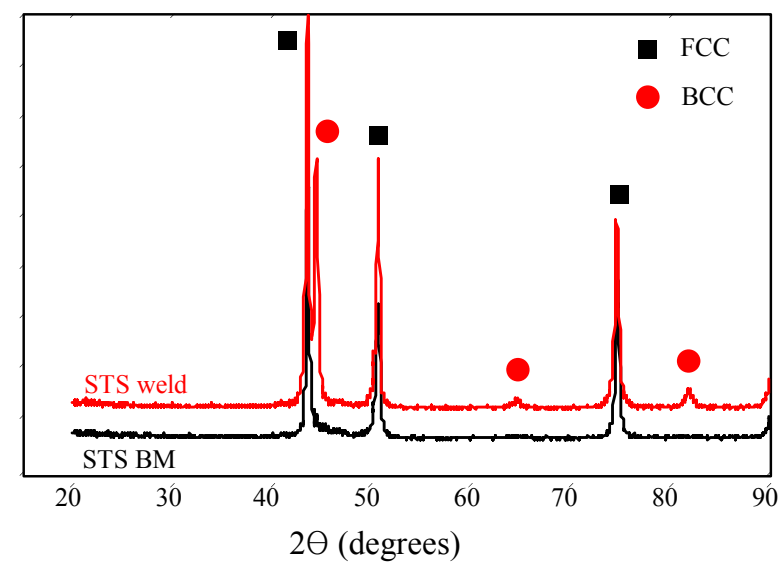

Fig. 4 XRD patterns of STS 304 BM and GTA weld using STS 308L filler

공존한다는 것을 알 수 있었다.

Fig. 5는 STS 308L 용접재료를 적용한 GTA 용접 부의 STS 304 모재에서 용접부 중심까지의 미세조직 거동을 나타낸다. STS 304 모재는 용체화 열처리 동 안 재결정 및 결정립 성장으로 약 $20 \pm 2 \mu \mathrm{m}$ 의 등축 정 결정립과 소량의 쌍정 (twin)을 포함하는 미세조직 을 가지며, Fig. 4에서 알 수 있듯이 주로 $\mathrm{FCC}$ 단상 으로 구성된 것을 확인하였다(Fig. $5 \mathrm{a}$ ). 용융선 부근의 열영향부 미세조직은 모재와 유사하였으나 결정립도가 모재보다 소폭 조대해졌으며(약 $22 \pm 2 \mu \mathrm{m}$ ), 특히 용 융선 근처에서 용접 열에 의해 결정립계를 따라 $\delta$-페라 이트의 생성을 확인하였다. 용융선 부근의 용접금속에
서는 용융선을 기준으로 동일한 결정방위를 가지며, 일 방향 성장되는 주상정 결정립이 관찰된다. 이러한 주상 정 결정립 간의 구분은 Fig. 5b의 inverse pole figure(IPF) map에서 결정 방위에 따른 색상 차이에 의 해 구별되며, 결정립 간의 계면을 결정립계로 나타내었 다. 또한 결정립 내에 저경각 결정립계로 구분되는 아 결정립계를 따라 $\delta$-페라이트가 관찰되었다. 일반적으로 스테인리스강의 용접 시 발생되는 용접열에 의하여 오 스테나이트 단상(A-모드), 오스테나이트- $\delta$-페라이트 $(\mathrm{AF}-$ 모드), $\delta$-페라이트-오스테나이트(FA-모드)의 2상 응고 를 통하여 $\delta$-페라이트가 정출되게 된다 ${ }^{8)}$. 또한 용접 시 발생되는 용융 및 응고과정으로 인한 인장/압축 응력 발 생에 의해 용융선 부근의 용접금속과 열영향부에서 국 부적으로 $\varepsilon^{-}$마르텐사이트가 관찰되었다 (Fig. $5 \mathrm{~b}$ ). 주 상정 결정립은 용접부 중심을 향하여 일방향으로 성장 되며, 용접부의 중심에서 등축정 결정립의 생성이 관찰 되었다. 용접부 중심의 미세조직은 조대한 결정립도를 가 지며, 오스테나이트와 약 $6.8 \%$ 의 vermicular $\delta$-페라 이트로 구성되어 있었다(Fig. $5 \mathrm{c}$ ). 이러한 결과는 Fig. 3 에서 $7 \%$ 로 예측된 페라이트 생성 수준과 거의 유사 하다.

\subsection{GTA 용접부의 기계적 특성}

3.2.1 GTA 용접부의 경도 특성

Figs. $6 \mathrm{a}$ 와 $6 \mathrm{~b}$ 는 STS 308L 용접재료를 적용한

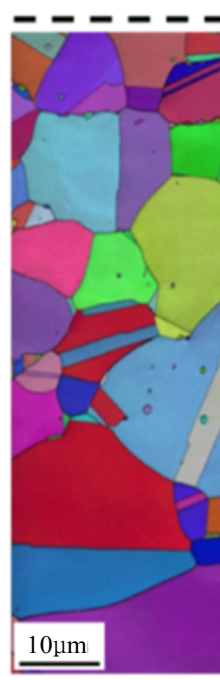

(a) 1

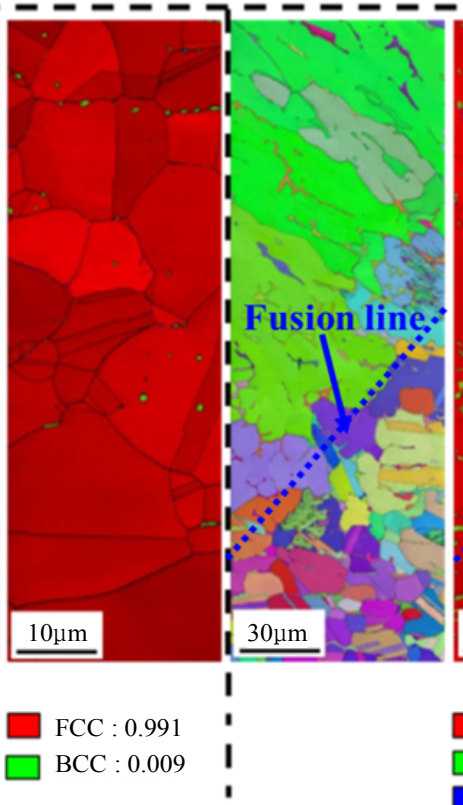

(b)

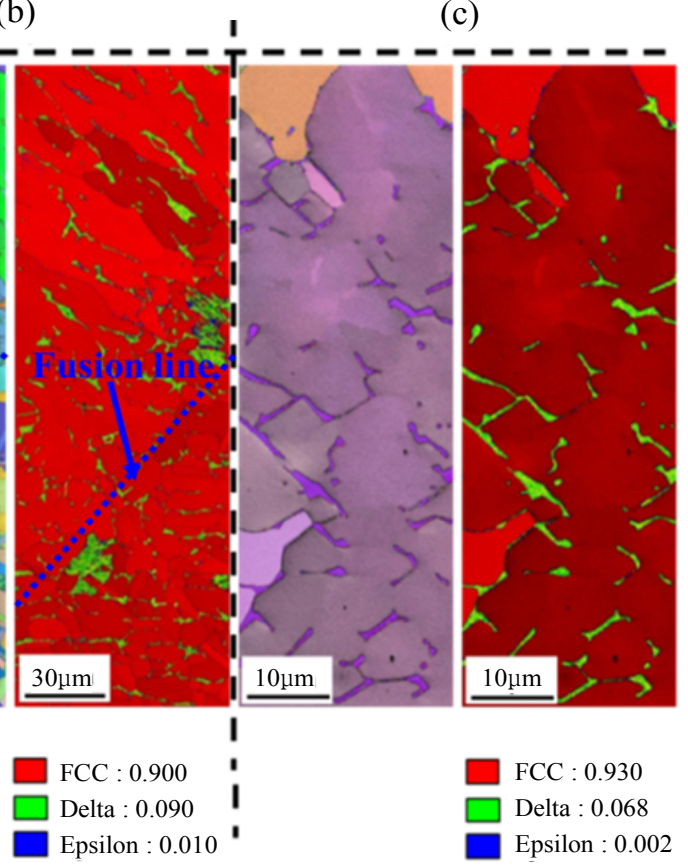

Fig. 5 Microstructural behavior of the GTA weld using STS 308L filler: (a) STS 304 BM, (b) fusion line, (c) STS 308L WM centerline 

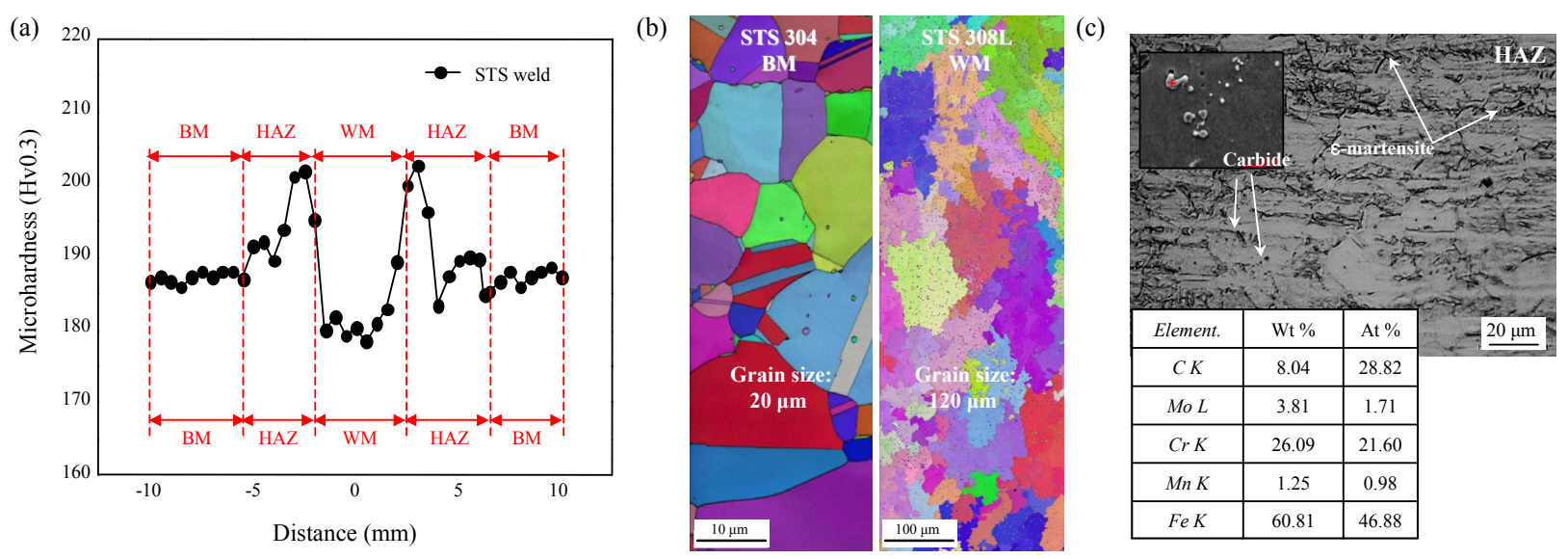

Fig. 6 Characteristics of GTA weld using STS 308L filler: (a) Hardness distribution, (b) grain size in BM/weld centerline, and (c) presence of carbide and $\varepsilon$-martensite in HAZ

GTA 용접부의 영역별 경도분포 및 결정립도를 각각 보여준다. Fig. 5a와 같이, STS 304 모재는 오스테나 이트 단상으로 구성되며, 약 $20 \pm 2 \mu \mathrm{m}$ 의 결정립도를 가지므로 모재의 평균경도는 약 $188 \pm 1 \mathrm{Hv}_{0.3}$ 로 측정 되었다. 용융선으로 갈수록 열영향부의 결정립도는 소 폭 조대화 되지만 용접열에 의한 $\delta$-페라이트의 생성으 로 인해 경도분포가 상승되는 경향을 보여준다. 또한, 용융선 부근의 열영향부에서는 경도분포가 급격히 상승 되는 경향이 관찰되는데, 이는 용융선 기준으로 열영향 부에 생성되는 $\mathrm{Cr}-\mathrm{rich}$ 탄화물 ${ }^{21}$ 및 국부적으로 생성 된 $\varepsilon$-마르텐사이트가 존재하기 때문으로 판단된다(Fig. $6 \mathrm{c})$. 용융선에서 용접금속의 중앙으로 갈수록 경도분포는 급속히 감소되며, 용접금속의 평균경도는 $180 \pm 1 \mathrm{Hv}_{0.3}$ 으로 모재보다 약 $8 \mathrm{Hv}$ 낮았다. 이러한 결과의 주된 원 인은 모재의 결정립도가 용접금속의 주상정 결정립(약 $120 \pm 2 \mu \mathrm{m}$ ) 보다 약 6 배 더 미세하기 때문인 것으

(a)

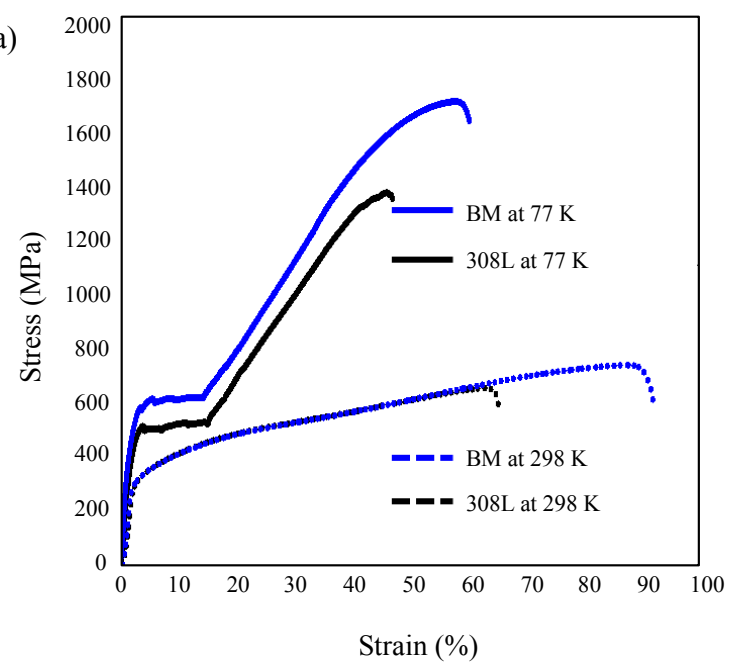

로 판단된다(Fig. 6b). 용접열원에 의한 용융 및 급냉 단계를 거치면서 열영향부의 결정립으로부터 주상정 덴 드라이트가 일방향으로 성장되므로, 열영향부의 결정립 도와 용접금속의 덴드라이트 암 간격은 거의 유사하였 다. 그러나 주상정 덴드라이트의 길이방향에 대한 결정 립도는 차이를 보였다.

\subsubsection{GTA 용접부의 상온 및 저온 인장 특성}

Figs. 7a와 7b는 STS 308L 용접재료를 적용한 GTA 용접부와 STS 304 모재의 stress-strain 곡선 및 인 장파단 위치를 나타낸 결과이다. 인장시험은 상온(298 K) 및 극저온 $(77 \mathrm{~K})$ 에서 수행되었다. STS 304 모재의 항복강도(YS)와 인장강도(TS)는 시험온도가 $298 \mathrm{~K}$ 에 서 $77 \mathrm{~K}$ 로 감소됨에 따라, 각각 $43 \%$ 와 $55 \%$ 증가되 었으나 연신율은 약 $30 \%$ 감소되었다. 인장시험 온도와 상관없이 용접부의 인장특성은 모재보다 열화된 결과를 (b)

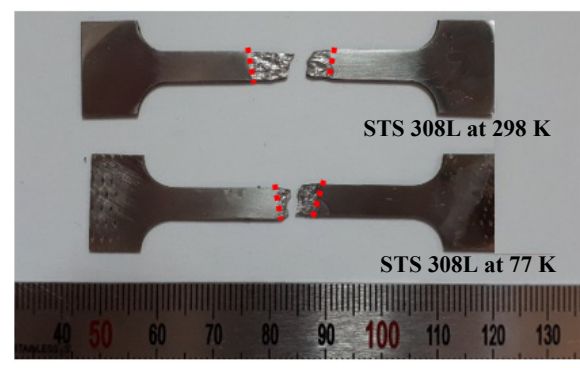

Fig. 7 Tensile properties of STS 304 BM and GTA welds using STS 308L filler tested at 298 and 77 K: (a) tensile stress-strain curves and (b) fracture positions in the welds 
보였다. Fig. $6 \mathrm{~b}$ 에서 설명하였듯이, 모재에 비해 조대 한 용접금속의 결정립도에 의해 상대적으로 약한 용접금 속의 중심선에서 인장파단이 발생되었기 때문이다. 하 지만 모재와 용접부의 극저온 인장특성은 상온특성 보 다 우수한 결과를 보였다. 특히, 모재부와 용접부 시험 편 모두 극저온에서 1 차 항복 이후 2 차 경화영역이 명 확히 나타나, 용접부가 모재와 동일한 저온 인장 특성 을 보임을 알았다 ${ }^{11,22)}$

Figs. 8 a 및 8b는 STS 308L 용접재료를 적용한 $\mathrm{GTA}$ 용접부의 상온 $(298 \mathrm{~K})$ 및 극저온 $(77 \mathrm{~K})$ 인장 파단 영역 부근 미세조직을 보여준다. 각 영역의 미세조직 은 EBSD의 inverse pole figure(IPF), coincidence site lattice(CSL) boundary, phase map을 적용하여 분 석하였다. 인장시험 온도와 무관하게 모든 용접 시험편은 용접금속의 중심선에서 파단 되었다. 용접부의 우수한 극 저온 인장특성의 메커니즘을 규명하기 위하여, 변형유기 소성 (Transformation induced plasticity, TRIP) 에 의한 변형쌍정(Deformation twin) 및 마르텐사이 트 상변태의 발생 여부를 관찰하였다. 변형쌍정의 생성 여부는 IQ image에 빨간색 선으로 표시된 $\Sigma 3$ 의 $\mathrm{CSL}$ boundary로 나타내었다. 또한, 마르텐사이트 상변태는 phase map을 통하여 마르텐사이트 생성여부 및 분율 을 관찰함으로써 주요 강화 메커니즘을 확인하였다. 일 반적으로 오스테나이트계 스테인리스강은 응력이 가해 지는 경우 변형쌍정 및 변형 유기 마르텐사이트 변태가 발생되며 이러한 조직은 적층결함에너지(stacking fault energy, SFE)에 의존한다. 금속재료의 내부에 존재하 는 원자배열의 결정구조가 파괴되면서 생성되는 적층결 함에너지는 합금원소나 온도, 결정립도 등에 따라 달라 진다. 특히, 온도변화 $(289 \mathrm{~K}-77 \mathrm{~K})$ 에 따라 적층결함 에너지가 크게 감소되어, 극저온에서 변형쌍정 및 마르 텐사이트 상변태의 분율이 급격히 증가된다고 알려져 있다 ${ }^{23,24)}$.

상온 용접부의 미세조직에서는 소량의 변형쌍정과 마 르텐사이트 상변태가 생성되었다. STS 308L 용접금속 의 경우, 합급성분 및 용접금속의 결정립도에 따라 상 온에서도 응력이 가해지면 변형쌍정과 마르텐사이트 상 변태가 생성될 수 있다. 반면, 극저온 용접부의 미세조 직은 변형쌍정과 마르텐사이트 상변태의 분율이 상온 용접부의 미세조직보다 높은 것을 확인하였다. 상온인 장 시험 시, 변형율이 증가될수록 적층결함에너지의 감 소를 유발하여 변형기구(슬립 $\rightarrow$ 쌍정 $\rightarrow \varepsilon$-마르텐사이 트)가 변화된다. 하지만 시험온도가 감소되면 변형율이 급속히 증가되어 변형기구의 분율이 증가되고 $\varepsilon^{-}$마르텐 사이트가 $\mathrm{a}$-마르텐사이트로 변태되므로 Fig. $8 \mathrm{~b}$ 와 같 이 변형쌍정과 $a$-마르텐사이트 상변태가 동시에 지배적 으로 생성되었다. 또한, 온도의 변화와 상관 없이 존재 하는 $\delta$-페라이트를 각 시험온도의 IPF 및 phase map 에 노란색 점선으로 나타내었으며, 인장시험 전에 용접 금속 내에 구성되어 있던 vermicular 형상의 $\delta$-페라이 트가 조각난 형태로 존재하는 것을 확인하였다. 그러나, 상온 시험편 보다 연신율이 감소되므로 STS 308L 용 (a)

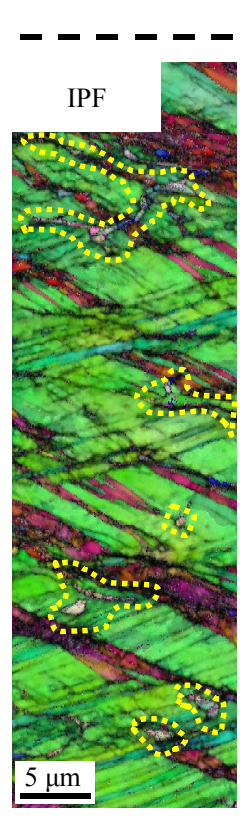

$\Sigma 3$ boundary

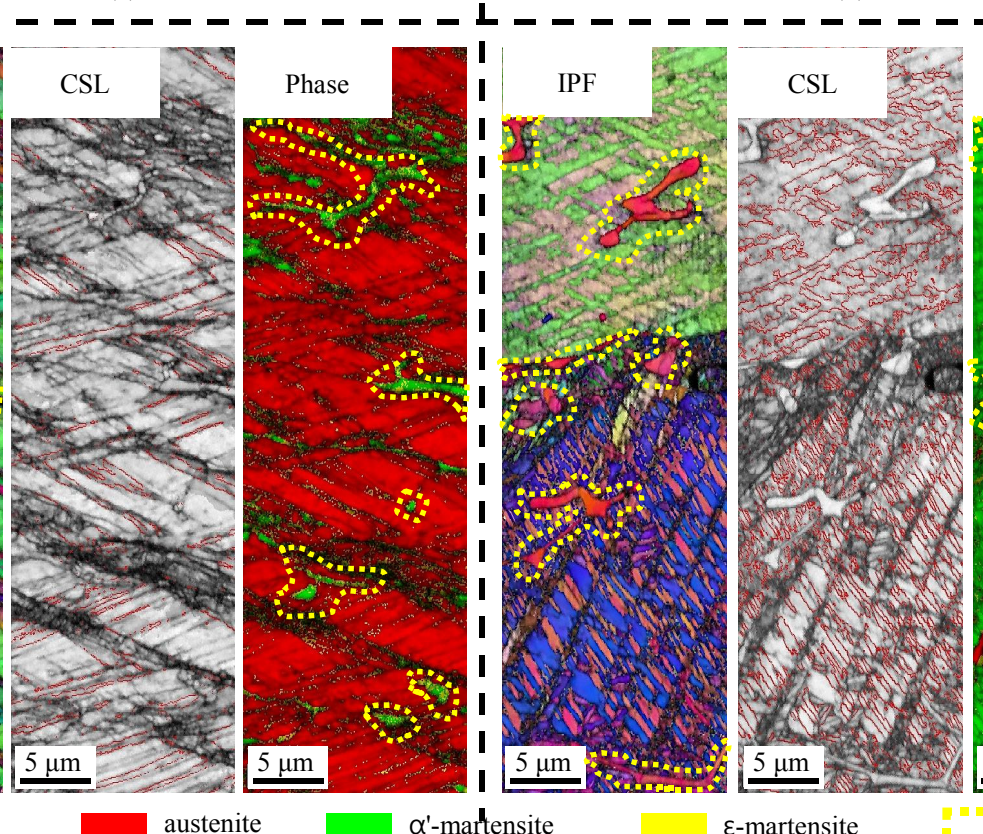

(b)

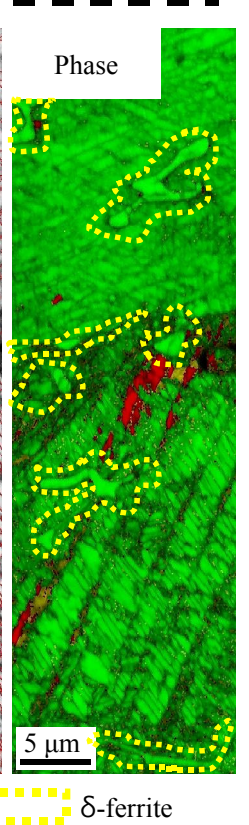

Fig. 8 EBSD microstructures near the tensile fracture position of the weld using STS 308L filler at various temperatures: (a) $298 \mathrm{~K}$ and (b) $77 \mathrm{~K}$ 

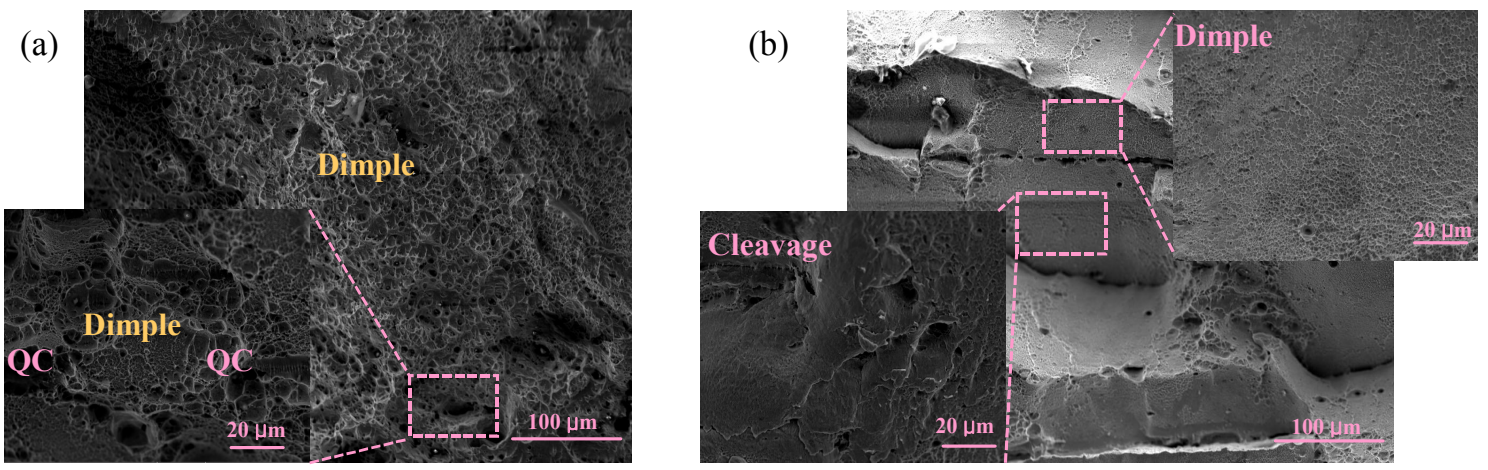

Fig. 9 Fracture surface morphology of the weld using STS 308L filler tested at various temperatures: (a) 298 K and (b) 77 K

접재료를 적용한 $\mathrm{GTA}$ 용접부의 우수한 극저온 인장 특성 메커니즘은 주로 마르텐사이트 상변태에 의한 강 화기구라고 판단된다.

Figs. 9 a와 9b는 상온 및 극저온에서 인장파단 된 GTA 용접부의 파면형상을 각각 나타내었다. 상온의 용 접부에서는 조대한 Dimple이 생성되었으며, 마르텐사 이트 상변태의 형성으로 인하여 국소적으로 취성파면이 관찰되었다(Fig. 9a). 하지만 극저온 용접부 파면의 Dimple 크기는 상온 시험편 보다 미세하였으며, 취성파면 의 분율 또한 극저온 용접부에서 더 높은 경향을 보였 다(Fig. 9b). 이것은 극저온 인장 시험 시, 변형쌍정 및 마르텐사이트 상변태의 형성이 지배적으로 생성 때문에 발생된 결과로 판단된다. 이러한 경향은 시험온도 저하 에 의한 적층결함에너지의 감소와도 관련 있다.

\section{4. 결 론}

본 연구는 STS 308L 용가재를 적용한 STS 304의 GTA 용접성과 극저온 환경에 대한 적용성을 조사하였 으며, 다음의 결론을 도출하였다.

1) STS 308L 용가재를 적용한 STS 304의 용접부 는 오스테나이트와 $\delta$-페라이트가 공존하였다. $\delta$-페라이 트는 용접열에 의하여 용융선 근처의 열영향부 결정립 으로부터 일방향 성장되는 주상정 덴드라이트의 interdendritic 영역에 $7 \%$ 정도 형성되었다.

2) STS 304 모재보다 용접금속의 평균경도가 낮은 원인은 모재의 결정립도가 용접금속의 주상정 결정립 보다 더 미세하기 때문이며, 용융선 근처의 열영향부에 서는 국부적인 $\varepsilon^{-}$마르텐사이트의 존재 및 carbide의 생성으로 인하여 모재보다 높은 경도를 가진다.

3) 인장시험 온도 $(298 \mathrm{~K}-77 \mathrm{~K})$ 의 변화와 상관없 이 모든 GTA 용접부는 STS 304 모재 보다 낮은 인 장특성을 보이므로 모든 용접부의 인장파단은 용접금속 의 중심선에서 발생되었다. 그러나 STS 308L 용접재
료로 제작된 STS 304 용접부는 STS 304 모재와 같 이 극저온 인장 특성이 상온에서 보다 우수한 결과를 보였다.

4) 극저온 인장 특성의 향상은 변형쌍정과 마르텐사 이트 상변태가 지배적으로 발생하였기 때문이었다. 하 지만 극저온의 GTA 용접부에서는 연신율이 감소되므 로 주된 강화 메커니즘은 가공유기마르텐사이트 상변태 라고 판단된다.

\section{Acknowledgment}

본 연구는 산업통상자원부(MOTIE, Korea)의 산업 기술혁신 사업(Grant No. 10080728)과 월드클래스 300 프로젝트 R\&D 지원사업(S2482209)으로 수행되 었습니다.

ORCID: Woosung Yang: https://orcid.org/0000-0001-6250-2258 ORCID: Byungrok Moon: https://orcid.org/0000-0002-4604-0898 ORCID: Hyunbin Nam: https://orcid.org/0000-0003-3152-9567 ORCID: Namhyun Kang: https://orcid.org/0000-0002-9460-5128

\section{References}

1. S. Kumar, H. T. Kwon, K. H. Choi, J. H. Cho, W. Lim and I. Moon, Current status and future projections of LNG demand and supplies: A global prospective, Energy Policy. 39(7) (2011) 4097-4104.

https://doi.org/10.1016/j.enpol.2011.03.067

2. J. H. Kim, S. W. Choi, D. H. Park and J. M. Lee, Charpy impact properties of stainless steel weldment in liquefied natural gas pipelines: Effect of low temperatures, Mater. Design. 65 (2015) 914-922.

https://doi.org/10.1016/j.matdes.2014.09.085

3. W. S. Park, M. S. Chun, M. S. Han, M. H. Kim and J. M. Lee, Comparative study on mechanical behavior of low temperature application materials for ships and offshore structures: Part I-Experimental investigations, Mater. Sci. Eng. A. 528:18 (2011) 5790-5803. 
https://doi.org/10.1016/J.MSEA.2011.04.032

4. Y. Xu, S. Zhang, H. Song, M. Cheng and H. Zhang, The enhancement of transformation induced plasticity effect on austenitic stainless steels by cyclic tensile loading and unloading, Mater Lett. 65:11 (2011) 1545-1547. https://doi.org/10.1016/j.matlet.2011.02.066

5. W. S. Park, S. W. Yoo, M. H. Kim and J. M. Lee, Strainrate effects on the mechanical behavior of the AISI 300 series of austenitic stainless steel under cryogenic environments, Mater Des. 31:8 (2010) 3630-3640. https://doi.org/10.1016/j.matdes.2010.02.041

6. Shankar V, Gill TPS, Mannan S.L, Sundaresan S. Solidification cracking in austenitic stainless steel welds, Sadhana. 28 (2003) 359-382.

7. J. Yu, M. Rombouts and G. Maes, Cracking behavior and mechanical properties of austenitic stainless steel parts produced by laser metal deposition, Mater. Design. 45 (2013) 228-235.

https://doi.org/10.1016/j.matdes.2012.08.078

8. E. J. Chun, H. Baba, K. Nishimoto and K. Saida, Precipitation of sigma and chi phases in $\delta$-ferrite of Type 316FR weld metals, Mater. Charact. 86 (2013)152-166. https://doi.org/10.1016/j.matchar.2013.10.003

9. F. Mas, C. Tassin, F. Roch, M. Yescas, P. Todeschini and Y. Brechet, Growth Morphologies and Primary Solidification Modes in a Dissimilar Weld between a LowAlloy Steel and an Austenitic Stainless Steel, Metals. 8:284 (2018) 1-21.

https://doi.org/10.3390.met8040284

10. C. Garion, B. Skoczen and S. Sgobba, Constitutive modelling and identification of parameters of the plastic strain-induced martensitic transformation in $316 \mathrm{~L}$ stainless steel at cryogenic temperatures, Int. J. Plast. 22 (2006) 1234-1264.

https://doi.org/10.1016/j.ijplas.2005.08.002

11. J. H. Hong, D. M. Keum, D. S. Han, I. B. Park, M. S. Chun, K. W. Ko and J. M. Lee, Mechanical Characteristics of Stainless Steel under Low Temperature Environment, JSNAK. 45:5 (2008) 530-537. https://doi.org/10.3744/SNAK.2008.45.5.530

12. T. Yuri, T. Ogata, M. Saito and Y. Hirayama, Effect of welding structure and $\delta$-ferrite on fatigue properties for TIG welded austenitic stainless steels at cryogenic temperatures, Cryogenics. 40 (2000) 251-259. https://doi.org/10.1016/S0011-2275(00)00033-3

13. J. H. Noh, S. G. Lee, H. J. Park and N. H. Kang, Effect of Composition on Strain-Induced Martensite Transformation and Tensile Stress-Strain Curve for Austenitic Stainless Steel, J. Weld. Join. 36(2) (2018) 28-33. https://doi.org/10.5781/JWJ.2018.36.2.5

14. A. Das and S. Tarafder, Experimental investigation on martensitic transformation and fracture morphologies of austenitic stainless steel, Int. J. Plast. 25(11) (2009) 2222-2247.

https://doi.org/10.1016/j.ijplas.2009.03.003

15. S. Curtze, V. T. Kuokkala, A. Oikari, J. Talonen and H. Hanninen, Thermodynamic modeling of the stacking fault energy of austenitic steels, Acta. Mater. 59(3) (2011) 1068-1076. https://doi.org/10.1016/j.actamat.2010.10.037

16. ASTM E8/E8M-08, Standard Test Methods for Tension Testing of Metallic Materials, ASTM international.

17. S. K. Park, H. J. Lee and J. H. Lee, Effect of Thermal Aging Induced Microstructure Evolution on Mechanical and Corrosion Properties of Delta-Ferrite in Austenitic Stainless Steel Weld, Korean J. Met. Mater. 56(4) (2018) 296-303. https://doi.org/10.3365/KJMM.2018.56.4.296

18. H. B. Nam, S. W. Park, N. K. Park, Y. S. Na, H. S. Kim, S. J. Yoo, Y. H. Moon and N. H. Kang, Weldability of cast $\mathrm{CoCrFeMnNi}$ high-entropy alloys using various filler metals for cryogenic applications, J. Alloy. Comp. 819 (2020) 153278. https://doi.org/10.1016/j.jallcom.2019.153278

19. J. Y. Jung, The Effects of Nitrogen Content and Cold Rolling Reduction on the Mechanical Properties of New 420-series Stainless Steel Strip having a Mesh As-Welded Structure by the Electroslag Cladding, $J$. Weld. Join. 35(6) (2017) 582-590. https://doi.org/10.5781/JWJ.2017.35.6.7

20. G. R. Mohammed, M. Iahak, S. N. Aqida and H. Abdulhadi, Effects of Heat Input on Microstructure, Corrosion and Mechanical Characteristics of Welded Austenitic and Duplex Stainless Steels: A Review, Metals. 7(39) (2017) 1-18. https://doi.org/10.3390/met7020039

21. S. Kumar and A. S. Shahi, Effects of heat input on the microstructure and mechanical properties of gas tungsten arc welded AISI 304 stainless steel joints, Mater. Des. 32 (2011) 3617-3623. https://doi.org/10.1016/j.matdes.2011.02.017

22. K. L. Ye, H. Y. Luo and J. L. Lv, Producing Nanostructured 304 Stainless steel by Rolling at Cryogenic Temperature, Mater. Manuf. Process. 29 (2014) 754758. https://doi.org/10.1080/10426914.2014.901534

23. M. H. Choi, J. H. Lee, H. B. Nam, N. H. Kang, M. H. Kim and D. W. Cho, Tensile and Microstructural Characteristics of Fe-24Mn Steel Welds for Crygenic Applications, Met. Mater. Int. 36(2) (2020) 240-247. https://doi.org/10.1007/s12540-019-00320-4

24. A. Das, Revisiting Stacking Fault Energy of Steels, Metall. Mater. Trans. A. 47A (2016) 748-768. https://doi.org/10.1007/s11661-015-3266-9 